\title{
O publicismo e a política conservadora do Brasil no século XIX
}

Luciana Rodrigues Penna ${ }^{1}$ (id)

\begin{abstract}
Este artigo enfoca os usos políticos do direito, mais especificamente os discursos mobilizados por frações da elite política imperial brasileira no formato de publicismo. O objetivo dessa abordagem é discutir a mobilização do conhecimento jurídico no âmbito das lutas desencadeadas no século XIX sobre a definição do modelo de Estado no Brasil, através da metodologia sócio-histórica. A pesquisa mostra os usos do publicismo e a invenção do constitucionalismo como armas do jogo político, que correspondem à concorrência intraelites no processo de construção e legitimação de um regime político de feição monárquica e centralizada.
\end{abstract}

Palavras-chave: política; juristas; publicismo; Brasil

\section{Introdução}

A abordagem do fenômeno político pode ser empreendida a partir de múltiplas perspectivas teóricas e metodológicas. Neste artigo o objetivo é problematizar a relação entre a trajetória de uma fração da elite política, seus modos de intervenção na qualidade de publicistas ou, mais especificamente, constitucionalistas, e a legitimação do regime político monárquico no Brasil. O caso empírico aqui discutido é o da mobilização política do constitucionalismo, tomando a produção de manuais de direito público e constitucional como uma estratégia no embate entre as elites imperiais brasileiras, especificamente no período do denominado Segundo Reinado (1840-1889). A partir do recorte temporal selecionado, o artigo procura discutir as relações entre política e direito, quando integrantes da elite política atuam na condição de juristas. Os resultados advêm de uma pesquisa de natureza qualitativa, com perspectiva sócio-histórica, baseada em amostra de publicações e análise de seu conteúdo, combinada com levantamento de trajetos dos autores.

Preliminarmente, é oportuno enfatizar que a problematização dos usos sociais da doutrina jurídica permite observá-la enquanto prática política, cujo sentido é contribuir,

\footnotetext{
1 Universidade Federal do Rio Grande do Sul, Programa de Pós-Graduação em Ciência Política (Núcleo de Estudos em Justiça e Poder Político). Porto Alegre (RS), Brasil. E-mail: <lucianarpenna@gmail.com>.
} 
através da mobilização teórica, para a reprodução ou contestação da ordem dominante. Dessa forma, os manuais jurídicos podem ser objeto de pesquisa sociopolítica direcionada a distintos contextos, como o do cenário fundacional do Estado brasileiro, no século XIX. A partir daí, sustenta-se a hipótese de que o constitucionalismo emergente no Segundo Reinado, que dá continuidade à análise jurídica das instituições iniciada com a Independência, funcionou como uma das estratégias de legitimação do regime monárquico, diante do desafio de superação das crises da década de 1830 que culminaram nas Regências e nas reformas descentralizadoras.

Dito de outro modo, na perspectiva do presente artigo, o constitucionalismo brasileiro elaborado no Segundo Reinado é analisado como esforço de contenção política, que contribuiu para a conformação do embate intraelites aos limites "constitucionais", isto é, para a acomodação das forças de oposição aos limites dados pelos contornos do regime monárquico centralista.

Importa destacar que tal perspectiva, embora ainda recente no Brasil, inspira-se em um conjunto de trabalhos nas ciências sociais que vêm mobilizando a historiografia para capturar a relação entre o social, o político e o jurídico, em diferentes recortes cronológicos. Analisando fenômenos sociais ou políticos em sua relação com o universo jurídico, tais problematizações situam-se em uma zona de fronteira entre as ciências sociais e a história (Silva, 2005). Dentre elas, aparecem abordagens sobre a trajetória do ensino jurídico no Brasil (Venâncio Filho, 2005), o bacharelismo liberal e a política do Império (Adorno, 1988), a judicialização da política e a estrutura do Poder Judiciário nacional (Burgos e Vianna, 1999), os juristas políticos da OAB (Vianna, 1985), o profissionalismo e a política no mundo do direito (Bonelli, 2002), o Poder Judiciário e a cidadania na Constituição da República brasileira (Koerner, 2010), a relação entre o Ministério Público e a política (Arantes, 2002), a nobreza togada e a formação da política de justiça no Brasil (Almeida, 2010), o papel dos juristas na formação do Estado brasileiro (Mota e Ferreira, 2010), a sociologia do campo jurídico, os juristas e os usos do direito (Engelmann, 2006) e o constitucionalismo e as batalhas políticas na Argentina (Engelmann e Penna, 2016). Também é relevante nesse caminho a discussão em torno da história das ideias políticas (Saldanha, 2001), da formação do pensamento conservador (Lynch, 2010) e da mobilização política dos intelectuais da geração de 1870 (Alonso, 2002).

Já no âmbito historiográfico, a discussão sobre o Brasil imperial é vigorosa e conta com um grande volume de contribuições ${ }^{2}$. Dentro desse amplo referencial, destaca-se a contribuição de estudos como o de Sérgio Adorno sobre os bacharéis do Império. Dessa análise, ressalta-se a múltipla inserção das elites políticas, em que os bacharéis em direito

\footnotetext{
2 Para adentrar no debate sobre a política e a produção teórica no Brasil do século XIX ver, dentre outros, os trabalhos de: Carvalho (2006), Costa (2007), Rodrigues (1974, 1975), Brasiliense (1979), Mattos (1987), Faoro (2000), Saldanha (2001), Alonso (2002), Kugelmas (2002), Oliveira (2002), Mercadante (2003), Neves (2003), Hallewell (2012), Junqueira (2011), Holanda (2004), Grijó (2005), Fausto (2006), Dutra (2004), Ferreira e Botelho (2010), Sodré (2004), Lynch (2010), Mota e Ferreira (2010), Alecrim (2011) e Prado (2012).
} 
constituíram a plataforma dos atores hegemônicos da cena política, um fenômeno identificado como "bacharelismo imperial" (Adorno, 1988).

A visão do papel fundamental que os bacharéis de direito do Império exerceram na vida política nacional estaria vinculada ao fato de que sua formação foi muito mais extraescolar, explicação para a "vocação política" liberal dos bacharéis, a partir do caso da escola de direito de São Paulo. Interessa aqui o fato de que as escolas de direito imperiais, e, no caso estudado, a escola paulista, não funcionariam propriamente como promotoras da "Ciência Jurídica", mas sim como espaços de socialização para os filhos das elites e trampolins para o seu ativismo político e cultural, pois eram lançados na vida profissional, sobretudo na vida política, a partir de sua inserção acadêmica. Enquanto celeiro de políticos-bacharéis que se tornaram homens políticos ligados aos ideários liberais, a vivência na escola jurídica teria fornecido as bases da emergência do "bacharelismo", modelagem de militância pela via das associações estudantis e da imprensa acadêmica. Essa realidade responderia à demanda do Estado por quadros qualificados. Assim, o "bacharelismo" explicaria a baixa produção jurídico-científica dos egressos desse ambiente.

A percepção de que os bacharéis liberais formados em São Paulo a partir de 1828 estiveram muito mais voltados ao exercício do publicismo jornalístico e às atividades militantes, ocupando, após formados, postos na esfera burocrática e nas carreiras políticas, ajudaria a explicar as razões do modesto investimento na produção de conhecimentos jurídicos através de obras doutrinárias no contexto do Império. Isso porque, conforme Adorno, mesmo a reduzida produção doutrinária dos políticos bacharéis formados em São Paulo não fora motivada por preocupações científicas. Seria, na realidade, efeito resultante do interesse pessoal desses agentes em adquirir um status intelectual (Adorno, 1988, p. 134).

Ao mapearem-se as produções teóricas e os trajetos dos políticos-bacharéis do Império, verifica-se, no entanto, a existência de uma dimensão coletiva no fenômeno do investimento em manuais jurídicos, o que permite indagar se, para além de algumas preocupações científicas e da busca de prestígio intelectual, haveria uma motivação política por trás de um conjunto significativo de publicações.

Em distinta perspectiva, o trabalho de Alonso (2002) debate o sentido do movimento intelectual da geração de 1870, apontado como mobilização política de contestação ao sistema imperial. Ao elencar os fatores da combinação de repertórios (nacional e europeu), comunidade de experiência e estrutura de oportunidades políticas, a autora aponta os usos políticos das produções intelectuais nesse cenário. Embora sustentada em outro eixo teórico, a análise do caso é vista como um uso político de produções teóricas. A produção intelectual do movimento da geração de 1870 teria sido uma forma de ação pública, o que adquire maior relevância porque situada no cenário de crise do Império, visto como contexto de inexistência de um campo intelectual dotado de autonomia relativa (Alonso, 2002, p. 39).

Outro ponto a destacar na abordagem de Alonso reside no argumento de que 
durante o Império não haveria um texto político fundacional, de modo que a ordem política teria contado mais com práticas do que com doutrinas expressamente formuladas para a sua legitimação (p. 52). Verifica-se, assim, que a análise não atribui significado político e simbólico à "Constituição", vista apenas como texto normativo outorgado em 1824. Com isso, não perquire o sentido político da mobilização de manuais de interpretação constitucional. Baseada na noção da existência de um consenso tácito em torno da ordem, uma vez que "ninguém se abalou em justificar os pilares da ordem imperial senão quando entraram em risco de desaparecimento" (Alonso, 2002, p. 52), não problematiza o viés político inscrito nas batalhas teóricas recorrentes entre frações da elite e travadas em torno da delimitação dos contornos do regime imperial, veiculadas (não somente, mas também) através de manuais de "interpretação constitucional" entre os anos de 1857 e 1882.

Em direção alternativa, aqui entende-se que o investimento em doutrina pode ter sido um trunfo de agentes identificados com a ordem para legitimar e difundir os princípios políticos monárquicos e conter as tomadas de posição divergentes entre as frações dominantes.

Outras análises com foco sobre o pensamento político brasileiro têm discutido o papel dos juristas em fenômenos políticos, especialmente no que tange ao processo de formação do Estado. Nesse sentido, Mota e Ferreira apontam a intervenção das elites jurídicas nos processos de formação da unidade nacional e na definição do formato das instituições estatais, assim como no próprio funcionamento delas (Mota e Ferreira, 2010, p. 5). Em relevante contribuição, Lynch retomou o debate sobre o sentido do pensamento conservador saquarema, no qual se incluem juristas imperiais, e enfatizou sua atuação como ponto de partida das futuras apropriações da luta antioligárquica na trajetória política brasileira (Lynch, 2010, p. 53).

Ao estudar as reconfigurações no campo jurídico a partir da redemocratização, Engelmann atualizou o debate apontando a emergência da "crise do ensino jurídico" como uma construção social dos próprios juristas, relacionada ao processo de diversificação do campo jurídico, engajando "teóricos" e "práticos" na disputa pelos sentidos do direito e levando a uma polarização entre "tradição" e "crítica" (Engelmann, 2006). Engelmann e Penna analisaram o caso argentino, apontando que o investimento de diferentes frações da elite política em interpretação constitucional foi uma das estratégias de legitimação de sucessivos regimes políticos, visando à sua formalização na técnica jurídica (Engelmann e Penna, 2016).

$\mathrm{Na}$ literatura internacional, encontra-se um conjunto de trabalhos significativos, especialmente os informados pelo programa de pesquisa lançado por Pierre Bourdieu, com base em análises sociológicas sobre elites e o campo jurídico. As principais contribuições dessa matriz teórica consistem no debate sobre a formação de uma nobreza de Estado (Bourdieu, 2013), sobre a força simbólica do discurso jurídico (Bourdieu, 1986) e sobre o processo de construção do Estado (Bourdieu, 2014). Para o autor, analisar a dimensão teórica da construção do Estado seria relevante para entender o que são os Estados 
modernos, e também o que estaria ocorrendo nos dias atuais: o que talvez seja o processo de sua destruição (Bourdieu, 2014, p. 470). Assim, a abordagem sociopolítica do papel dos debates jurídicos foi um viés sistematicamente ressaltado pelo autor, que propôs a releitura da história dos acontecimentos do direito, procurando vê-los como resultantes das discussões em que a dimensão teórica da construção do Estado é relevante (Bourdieu, 2014, p. 471).

Estudos com perfil sociopolítico sobre diferentes locais e períodos emergiram a partir dessa linha, trazendo subsídios para investigar fenômenos de mobilização social e de construção de causas políticas através do direito (Agrikoliansky, 2010; François, 1996, 2003; Chevallier e Lochak, 2016; Dezalay, 1993; Dezalay e Garth, 2015; Sacriste, 2011; Vecchioli, 2019). Tais discussões indicam que não seria somente nas condições das democracias contemporâneas, caracterizadas em geral por uma maior autonomização do campo jurídico em relação ao mundo político, que o direito seria mobilizado por grupos sociais como ferramenta de luta política. Contextos como o do século XIX e da primeira metade do século $X X$ também apontam a emergência de uma forte imbricação entre política e direito, como indica o estudo sobre a atuação dos professores de direito constitucional na legitimação da ideologia republicana durante a Terceira República francesa (Sacriste, 2011) e a discussão sobre o engajamento doutrinário dos publicistas franceses Maurice Hariou e Léon Duguit em face do advento da Primeira Guerra Mundial (Blanquer e Millet, 2015).

Nesse sentido, é importante referir que o investimento, a elaboração, a mobilização e os usos sociais e políticos da produção intelectual de profissionais do direito jamais ocorrem no vazio, mas são elementos sempre inseridos em um tempo e um espaço sociais específicos. Portanto, ao problematizar a mobilização do publicismo jurídico enquanto fenômeno político, é necessário relacionar essa mobilização ao contexto, o que faz da abordagem sócio-histórica uma via promissora (Charle, 1997; Buton e Mariot, 2009). Também Vecchioli empregou essa metodologia para analisar o processo de construção e de consolidação da expertise em direitos humanos no século XX, enfocando a mobilização dos juristas no contexto argentino (Vecchioli, 2019).

Reconhecendo a força simbólica representada pelo direito, tais análises atentam para as categorias de juristas que detêm o monopólio de dizer o sentido correto das normas, força crescentemente mobilizada pelos atores políticos como recurso de legitimação de seu poder (Bourdieu, 1986). Isso converge para estudos da juridicização do político, analisada em diferentes contextos, como no caso francês (Charle, 1997; Chevallier, 1993; Commaille, Dumoulin e Robert, 2010). A pesquisa sócio-histórica, combinada com a técnica da prosopografia (Stone, 2011), possibilita investigar características comuns de um coletivo, buscando identificar correlações internas a um grupo e também correlações com outras formas, comportamentos e espaços sociais (Stone, 2011, p. 115).

Em seu trabalho, Charle (1997) destacou a afirmação de diferentes categorias de 
profissionais do direito na França do século XIX como fração importante da elite burocrática que transpassa o Ancien Régime ${ }^{3}$. Segundo Dezalay (1993), é necessário empreender uma história social das batalhas doutrinais, pois o espaço da produção de repertórios jurídicopolíticos é marcado tanto por lutas internas quanto por clivagens concorrenciais ligadas às disputas profissionais com outros campos, em torno do monopólio do discurso oficial sobre o Estado.

Outros enfoques ilustrativos dessa abordagem que também fornecem pistas de investigação são as análises sobre o engajamento cívico de publicistas. Blanquer e Millet analisaram o caso dos juristas franceses Hauriou e Duguit diante do cenário da Primeira Guerra Mundial, partindo da questão sobre o estatuto do conflito no pensamento e no trajeto desses dois publicistas e, a partir daí, discutem os usos do conflito no âmbito da doutrina (Blanquer e Millet, 2015). Discussões sobre a dimensão política e social inscrita na construção e difusão de doutrinas constitucionais e sua relação com os trajetos dos especialistas apareceram em Lacroix e Lagroye (1992), François (1996, 2003), Sacriste (2011), Poirmeur e Bernard (1993) e Poirmeur e Rosenberg (1989) como estudos que fornecem elementos para a análise a partir do caso francês. Com base nesses trabalhos verifica-se que desde os anos 1960, na França, ocorre um fortalecimento do debate constitucional resultante da afirmação do caráter jurisdicional da atuação do Conselho Constitucional e do intenso trabalho de construção doutrinária entre os juristas (Poirmeur e Rosenberg, 1989, p. 233).

Conforme Sacriste (2011), a mobilização do direito constitucional pelos políticos republicanos no cenário francês de fins do século XIX fez emergir a figura do constitucionalista, e o papel político assumido pelos professores de direito constitucional das faculdades de direito foi crucial para a legitimação da causa republicana. Lacroix e Lagroye (1992) analisaram as tomadas de posição dos constitucionalistas franceses no início da década de 1990 e demonstraram que eles romperam com a tradicional clausura universitária, inserindo-se na esfera midiática em que concorrem pela atenção da opinião pública com outros profissionais, como jornalistas, economistas e cientistas políticos.

\section{A dimensão doutrinária da política no Segundo Reinado}

Analisar em perspectiva sócio-histórica a produção doutrinária das elites do Segundo Reinado não significa desconsiderar a relevância da contribuição desses autores para o nascimento do direito constitucional brasileiro, mas pode fornecer elementos explicativos sobre as condições em que se processou essa emergência do constitucionalismo, enquanto tipo específico de discurso de Estado. Portanto, o objetivo de realizar a sociogênese da mobilização do publicismo em torno das disputas políticas

\footnotetext{
${ }^{3}$ Charle (1997) compara dois modelos de reprodução social: um primeiro ligado ao Ancien Régime e ancorado em estratégias de poder tradicionais, baseadas na formação e manutenção das grandes famílias de juristas, e outro que emerge com a ascensão da burguesia, com efeitos de diferenciação social.
} 
funciona também como cautela diante do risco de adesão à representação ideológica dos agentes situados no campo jurídico, via de regra, universalista, sendo decisivo ultrapassar a análise nativa do debate doutrinário, que o apresenta como legalista, técnico, abstrato e neutro, ou seja, resultante unicamente do diálogo científico entre especialistas, portanto, autônomo em relação às polarizações políticas. A leitura sócio-histórica auxilia a desnaturalizar tais discursos, ou seja, adentrar na construção social da dimensão doutrinária do político.

A produção de obras jurídicas pode ser tomada, assim, como um dos fatores que contribuem para a formação do discurso oficial do Estado, baseado em um ideário comum sobre políticas públicas ou mesmo sobre o regime político. Essa abordagem contribui, portanto, para a análise do papel da expertise jurídica nos processos de reprodução e legitimação de fenômenos políticos em distintos contextos históricos do cenário brasileiro. Quando se observa que frações da elite política mobilizaram a teorização do direito como uma ferramenta de contestação ou legitimação de regimes políticos, insere-se a doutrina constitucional no processo de definição jurídica das instituições políticas. Vê-se, então, que o poder simbólico dos constitucionalistas consiste em sua condição de experts da interpretação do dispositivo constitucional, a partir da qual desfrutam do trunfo de elaborar argumentos para a fundamentação tanto das decisões judiciais dos tribunais e cortes constitucionais quanto dos atos decisórios dos governos.

Por isso, tomando o debate constitucional como debate político, pode-se melhor compreender o fenômeno de modelagem da política pelo direito (François, 1996, 2003), não apenas a partir da análise de conteúdo dessas produções, mas também com base em dados sobre as posições e tomadas de posição inscritas nos trajetos dos agentes engajados nas batalhas políticas do período. O Segundo Reinado, iniciado em 1840, pode ser considerado um contexto de fortes mudanças relacionadas à meta de uma fração da elite comprometida com a consolidação do Império, em um período em que se iniciou inclusive a urbanização do Brasil (Sodré, 2004, p. 57). Tal contexto de mudanças indica que a mobilização da dimensão doutrinária da atuação política dos bacharéis não se deu em um quadro de vazio legal e institucional. Isso porque, apesar da Abdicação de D. Pedro I, em face da Revolução de 7 de abril de 1831, já havia entrado em vigor, outorgada em 1824, a Constituição, com um texto que estabelecia, no plano institucional, a monarquia, o Poder Moderador, a Câmara temporária, o Senado vitalício e o Conselho de Estado. Ou seja, o cenário institucional já estava moldado juridicamente e a centralização política estava instituída pela formalização do regime na regra constitucional (Brasiliense, 1979, p. 17).

Ressalta-se que, na perspectiva aqui adotada, a doutrina não é tomada como mera técnica jurídica nascida em decorrência da necessidade acadêmica de "interpretar a Constituição". De modo diverso, lança-se a hipótese de que a produção de manuais de direito público e constitucional foi vista como ferramenta estratégica pelos políticosbacharéis no contexto de reestruturação institucional da década de 1840, funcionando no apoio à articulação política que culminou no denominado "Regresso". As condições em que 
se desenrolou o debate jurídico travado entre as elites políticas demonstram que ele se inseriu no cenário após a crise que levou à renúncia de Diogo Feijó e às rebeliões provinciais do contexto regencial (1831-1840), um quadro de grande instabilidade política, de acirramento de lutas e de ocorrência de movimentos de tom contestatório da ordem monárquica (liberais, republicanos, federalistas) que emergiram em várias regiões do país, como, no caso do Rio Grande Sul, a Revolução Farroupilha, deflagrada em 1835.

É importante salientar que um dos efeitos desse cenário de crise, agravado com a Abdicação do primeiro imperador, foi a aglutinação de interesses e visões de mundo em torno de duas agremiações políticas. Assim, a descentralização política implementada pelas reformas "liberais" do início dos anos 1830, como o Código Criminal de 1832 e o Ato Adicional de 1834, e os movimentos revolucionários do Período Regencial (1831-1840) foram os fatores que motivaram a fundação dos dois partidos que se mantiveram dominantes na vida política até o final do Império: o Partido Liberal e o Partido Conservador (Carvalho, 2006, p. 204). Os partidos políticos no Brasil surgiram, portanto, a partir de um cenário de confrontos e instabilidade política, aspecto que necessita ser enfatizado de modo a se compreender que a década de 1840 não representou um período de passividade e previsibilidade política, mas de desafio às elites políticas no sentido de encontrar estratégias eficazes para apaziguar ou, ao menos, controlar os níveis das disputas que já haviam iniciado na década anterior e assumido caráter violento.

O problema político central, na visão dos políticos do eixo conservador, era a "desordem" que ameaçava as instituições imperiais, a qual foi justificada pela persistência de várias ações contestatórias durante os anos 1840, como a Revolta Liberal de 1842, movimento que envolveu São Paulo, Minas Gerais e Rio de Janeiro. Também exemplifica esse cenário convulsionado por mobilizações contestatórias do regime a Revolta Praieira de 1848, em Pernambuco (Fausto, 2006, p. 95). Tais cenários de "crise objetiva", combinados com o discurso "crítico" sobre a ordem, podem ser considerados componentes de um contexto propício para a "ruptura herética para com a ordem estabelecida e para com as disposições e representações que ela engendra em torno dos agentes moldados segundo suas estruturas" (Bourdieu, 1981, p. 69).

Portanto, é relevante frisar que no período entre 1830 e 1840 repercutia a disputa política que adquiriu um formato intensificado e polarizado, polarização esta que colocava às elites políticas o dilema de aderir a uma posição conservadora centralista (saquarema) ou a uma liberal descentralista (luzia) para se manterem no âmbito das "ideologias da ordem". À contestação situada para além dessa fronteira da "constitucionalidade" sobraria apenas a posição "radical", "exaltada" e "republicana". Como esta última opção atentava contra o próprio regime instituído, que era a monarquia, implicava adotar uma via de ação camuflada, por ser "contra a ordem", isto é, "inconstitucional", uma espécie de "impossível político". Logo, ao republicanismo (e até certo momento, ao abolicionismo) só restaria uma opção "revolucionária". Dessa forma, os partidos Conservador e Liberal representaram, durante um período significativo do Segundo Reinado, os únicos caminhos "admitidos" para 
a ação política, pelo menos até fins da década de 1860 . Ambos não colocavam em questão a forma monárquica do regime, semelhança que auxilia a explicar o fato de ser comum a passagem de políticos de um campo para o outro (Fausto, 2006, p. 98). Mais adiante, a análise dos trajetos dos constitucionalistas auxiliará a entender em que condições o constitucionalismo brasileiro que emergiu no Segundo Reinado restou contido dentro do binômio "liberalismo x saquaremismo".

Com relação aos aspectos da distinção programática ou ideológica entre essas agremiações políticas, não há consenso entre os especialistas. As posições dos historiadores são bastante diversas: para alguns não houve diferença significativa entre $a^{a m b o s^{4}}$, enquanto para outra linha, sustentada em argumentos variados, houve sim uma significativa distinção ${ }^{5}$. Na presente abordagem não se visa estabelecer qual das posições historiográficas seria a correta. Segue-se a orientação de que, se houve diferenças, houve também semelhanças entre os luzias e os saquaremas. No entanto, a dimensão importante que não pode ser desprezada é aquela que aponta não apenas as distinções e/ou as similitudes, mas, sobretudo, a hierarquia política entre ambos. Sob esse viés, da configuração de um Tempo Saquarema, se questiona em quais condições foram mobilizadas estratégias e recursos para a manutenção da posição de superioridade política do Partido Conservador (Mattos, 1987, p. 128) e o modo como os agentes do campo liberal buscaram enfrentar essa supremacia. É nesse viés que se pode inserir a produção de manuais de "interpretação constitucional" durante o Segundo Reinado.

Em seu relato, Américo Brasiliense sustentou que, após a Abdicação, três partidos entraram em combate pelo monopólio do poder: o Partido Restaurador (que aspirava à volta de D. Pedro I), o Partido Liberal (que defendia reformas constitucionais, porém conservando a monarquia) e o Partido Republicano (defensor da abolição da monarquia). No entanto, o Partido Liberal estava dividido entre "liberais moderados" e "liberais exaltados", estes defensores de uma monarquia federativa. A "ala" moderada tornou-se majoritária e dominante, mas firmou um acordo com os "exaltados" para unificar a "bandeira liberal" e conseguir implantar o programa de reformas (Brasiliense, 1979, p. 17). O programa de reformas do Partido Liberal, apresentado em 1832, foi aprovado na Câmara dos Deputados, estabelecendo a monarquia federativa e a tripartição de poderes e extinguindo o Poder Moderador, o Conselho de Estado e a vitaliciedade do Senado. A Reforma também propunha transformar os Conselhos Gerais das províncias em Assembleias provinciais eleitas, instituía a eleição bienal para a Câmara dos Deputados e a distinção entre os impostos nacionais e os impostos provinciais, garantindo que as províncias obtivessem receita própria. Enviado ao Senado, este alterou praticamente tudo, através de emendas.

\footnotetext{
4 Para essa questão, ver Carvalho (2006, p. 202). Também Ilmar de Mattos aponta que, com argumentos diferentes, Oliveira Vianna, Caio Prado Jr., Maria Isaura Pereira de Queiroz e Nestor Duarte afirmam ser apenas aparente a distinção entre os partidos Conservador e Liberal (Mattos, 1987, p. 130).

5 Para Mattos seria o caso de João Camilo de Oliveira Torres, Fernando de Azevedo, Manoel Maurício de Albuquerque, Azevedo Amaral, Raymundo Faoro e José Murilo de Carvalho (Mattos, 1987, p. 131).
} 
A Câmara rejeitou as emendas, e houve a fusão das duas casas legislativas para sua discussão e votação (Brasiliense, 1979, p. 19). Em 1834 foi aprovado o Ato Adicional à Constituição, que ficou muito aquém do programa liberal, mas suprimiu o Conselho de Estado. Esse momento marca a fase das Regências, sendo a primeira delas encabeçada pelo liberal Diogo Feijó, que renunciou em 1837 pela falta de apoio parlamentar. Com a renúncia do regente, iniciou-se um "levante" de parlamentares a defender que o obstáculo à "ordem política" e à "paz social" consistia no próprio Ato Adicional de 1834 (Brasiliense, 1979, p. 21). Dessa forma, era necessário "interpretá-lo", o que, nesse caso, significou reduzir seu alcance. Esse papel foi assumido pelos políticos-bacharéis conservadores.

Para os saquaremas, a causa da crise foi atribuída ao Ato Adicional de 1834, que enfraqueceria a autoridade, uma vez que atacava o governo e comprometia a unidade nacional (p. 21). Daí se originou o Partido Conservador, organização cujo programa não necessitava ser elaborado e apresentado formalmente pois, segundo afirmava José de Alencar, era o próprio texto da Constituição de 1824 (Paranhos, 2013, p. 38). Logo, até 1841 , com as medidas adotadas no âmbito do "Regresso de 37", enraizou-se um processo de centralização política, com a sustentação do papel central dos membros do Partido Conservador de "defender a Constituição" (Paranhos, 2013, p. 38). Portanto, o posicionamento de maior ou menor adesão ao texto original da Constituição de 1824 era um fator que diferenciava conservadores puros ou saquaremas de conservadores liberais, reformistas ou progressistas.

As medidas centralizadoras ou o "Regresso" prosseguiram após 1840, com a reabertura do Conselho de Estado, em 1841, anteriormente extinto pelo Ato Adicional de 1834. Por força da aprovação da Lei de Interpretação de 1841 , todo o aparato administrativo e judiciário retornou ao controle do poder central (Fausto, 2006, p. 94). O caso de José de Alencar ilustra um político-jurista que afirmava que defender a Constituição de 1824 era a "missão divina" do Partido Conservador, implicando a adesão aos valores da "tradição, "moderação", "prudência" e "reforma gradual" em um sistema político em que "o Rei reina, governa e administra" (Paranhos, 2013, p. 38).

Essa adesão maior dos políticos conservadores à defesa da "Constituição", como se o texto originário de 1824 não houvesse sido modificado com o Ato Adicional, permite observar a perspectiva da batalha pela superioridade política do campo conservador através da apropriação da "interpretação constitucional" no Segundo Reinado. Tal supremacia não era evidente em um plano quantitativo, em face de que a proporção de filiação dos ministros ao Partido Conservador e ao Partido Liberal distinguia-se pouco (43,89\% filiavam-se ao primeiro, e 49,64\%, ao segundo). Da mesma forma, os gabinetes ministeriais conservadores foram 14, contra 15 ministérios liberais (Carvalho, 2006, p. 211), uma diferença ínfima.

No entanto, o fator que aponta a existência e a permanência da dominação conservadora consiste na duração dos ministérios conservadores no poder, em relação aos liberais: foram 26 anos de governo saquarema, contra 13 anos de governo luzia, isto é, o 
Segundo Reinado representa o dobro de saquaremismo em comparação ao domínio da fração dita liberal (Carvalho, 2006, p. 210). Por tal ótica, interessa identificar as condições do empreendimento de legitimação do regime monárquico no processo de consolidação do Segundo Reinado, enquanto defesa do formato monárquico e centralista do Estado nacional (Mattos, 1987, p. 126).

Destaca-se também que, em face de o Brasil ser um país monárquico cercado por Repúblicas, a elite política (e, sobretudo, a fração "conservadora" da elite imperial) foi desafiada a elaborar modos de justificação para essa condição, que era oposta à realidade política internacional. Essa elite foi encarregada de explicar por que o Brasil seria um caso "especial" e poderia, então, ser "diferente" dos demais países americanos. A defesa de instituições como a monarquia, a titularidade do Poder Executivo e do Poder Moderador pelo imperador, a manutenção do Conselho de Estado e da vitaliciedade do Senado eram tarefas dos agentes ilustrados, onde figuravam, especialmente, os juristas.

O encargo legitimador do regime monárquico demandou que diversos recursos fossem mobilizados, implicando adentrar vários meios culturais, como o periodismo, a arte, as ciências, o teatro, a historiografia e a literatura. Através dessa última, atuaram agentes como José de Alencar, Gonçalves de Magalhães e Gonçalves Dias. Assim, o político conservador José de Alencar exemplifica os usos políticos da literatura para fins de construir a imagem idealizada do indígena como o "herói" nacional, de modo a celebrar a miscigenação da "raça nativa" com o europeu português e não tocar na questão escravista (Mattos, 1987, p. 127).

Portanto, identificar os marcos desse contexto é fundamental para a compreensão da mobilização política de obras jurídicas na forma de "interpretação constitucional" que se processou entre 1850 e 1888, para o que se adota a perspectiva de que houve semelhanças e diferenças entre as demandas dos dois partidos, mas também de que se consolidou uma "direção saquarema" de longa duração. Esta consistente em impor aos "luzias" a derrota no campo de batalha armada, ao confinar as suas pretensões à "revolução" a meras "rebeliões" (Mattos, 1987, p. 129), e a derrota na batalha teórica pelo sentido do regime. Para tal, uma das estratégias foi o constitucionalismo. Esse aspecto é elucidativo por situar o funcionamento das duas escolas jurídicas, criadas em 1827, dentro do panorama histórico marcado por estas características: o avanço de uma dominação conservadora e a reação dos oposicionistas "liberais".

Também permite observar os percursos dos agentes e o teor de seus manuais de "interpretação constitucional" dentro desse enquadramento, buscando identificar as posições alinhadas com o saquaremismo e os usos identificados com a contestação "liberal". Tendo isso em vista, entende-se que, desde a formação das primeiras turmas graduadas em direito no Brasil, a partir de 1832, uma parte da elite de bacharéis seria recrutada para a tarefa de mobilização do poder simbólico comprometido com a sustentação do regime imperial. O discurso jurídico era bastante adequado para esse fim e foi utilizado pelos agentes de ambos os partidos, ainda que em seu interior não houvesse 
consenso, identidade de origem social, nem homogeneidade ideológica6 ${ }^{6}$

O foco é colocado, portanto, na verificação da lógica social subjacente a esse processo de constituição de um agrupamento e de suas posições (Coradini, 2008, p. 16). Considera-se como premissa que uma das formas pelas quais os políticos-bacharéis afirmavam a cientificidade da sua "doutrina" consistia em aproximar a sua elaboração textual das regras de formatação que regiam a produção de trabalhos científicos em outras "ciências" ou disciplinas". Esse aspecto possibilita indagar sobre a função política dessa "cientificização das instituições" implementada através da colocação de temas políticos na forma de discurso jurídico.

\section{Os constitucionalistas do Segundo Reinado e o compromisso monárquico}

Como referido, a coleta de dados empíricos que sustentou a análise orientou-se pela hipótese de que o investimento de um grupo de agentes em doutrina constitucional não se explicaria, unicamente, por motivações acadêmicas, nem pela existência oficial de uma "Constituição" a interpretar, no caso a Constituição de 1824 (e suas reformas posteriores). Logo, seria possível tomar esse investimento também como uma estratégia de mobilização do saber jurídico na construção de causas políticas e mesmo de crenças voltadas à formação de uma cultura política, evitando explicitar seu próprio engajamento no jogo político. Dessa forma, teria sido possível interpretar as instituições políticas a partir de um lugar neutro por definição: a doutrina jurídica.

Leve-se em conta que a produção de manuais jurídicos também teria sido afetada pelas oscilações do mercado cultural, pois, durante o Segundo Reinado, ocorreu uma expansão editorial, simultaneamente ao fomento do comércio de livros no Rio de Janeiro. A instalação das livrarias francesas passou a servir à nova demanda por obras, gerada com a fundação das escolas superiores que incluíram no currículo a cadeira de Direito Público e Constitucional, denominada de Análise da Constituição do Império (Alecrim, 2011, p. 60).

Para a composição da amostra representativa, partiu-se de manuais de interpretação constitucional publicados durante o Segundo Reinado, ou seja, na segunda metade do século XIX. Esse recorte temporal se justifica, como acima referido, porque mais exatamente de 1850 em diante tem-se o momento de "consolidação" da Monarquia sob o comando de D. Pedro II, sustentando a denominada política da "Conciliação", um

\footnotetext{
${ }^{6}$ Como a distinção "interna" ao campo liberal que os distinguia em: liberais "históricos", liberais "moderados" e liberais "radicais" (quase republicanos). Para essas distinções, ver Brasiliense (1979).

7 Esse aspecto foi também salientado por Guedes: "Sendo a doutrina um Discurso Científico, obedece às normas para trabalhos científicos, firmando teorias ou estabelecendo interpretações sobre a ciência jurídica; dessa forma, desenvolvendo uma reflexão contínua. Tem como premissa a atividade de fazer persuadir. As marcas são aquelas utilizadas para construir a própria imagem dentro dos padrões necessários para ser legitimada. Assim, podemos admitir que os discursos doutrinários existem com a finalidade de descrever certa situação, como uma reflexão científica, mas acabam tendo outra finalidade na medida em que servem para elucidar dúvidas, sendo citadas na lógica da argumentação do discurso decisório. Por conseguinte, a doutrina acaba por adquirir natureza prescritiva, pois, ao preencher uma lacuna na lei, ganha força de lei, tornando-se norma para casos semelhantes" (Guedes, 2011, p. 32).
} 
momento propício para a análise da relação entre o publicismo e as demandas do regime. Por outro lado, esse contexto também apresenta características de ascensão cultural e econômica do Brasil, motivada por fatores como a aprovação da Lei de Extinção do Tráfico Escravo (1850) e a expansão da produção cafeeira e dos investimentos em infraestrutura urbana (transportes, telégrafos, energia a gás), cenário que também pode ser interpretado como propício à maior mobilização do direito. Sendo o Segundo Reinado, sobretudo após 1850, o momento em que se situa o novo ímpeto de investimentos em manuais de doutrina constitucional, encontra-se aqui um importante ponto de análise: como os manuais doutrinários repercutiram essa nova etapa do regime imperial? Em primeiro lugar, pergunta-se quais os efeitos da hierarquização do espaço político sobre a doutrina constitucional, um cenário por longo tempo polarizado entre o Partido Conservador (Saquarema) e o Partido Liberal (Luzia). Em segundo lugar, procura-se identificar a diferenciação das formas e do teor das tomadas de posição política dos agentes através dos seus manuais de direito.

Os dados que embasam a análise constituem amostra coletada a partir de um conjunto de referências biográficas, originárias de fontes primárias (manuais impressos ou digitalizados) e de fontes secundárias (obras sobre a produção jurídica imperial, biografias das elites imperiais, dicionários bibliográficos e biográficos, bem como sítios de documentação biográfica). No Quadro 1, visa-se adentrar no âmbito da representação social dos políticos-bacharéis, magistrados e professores de direito do Segundo Reinado, na figura de "intérpretes da Constituição". Ou seja, aqui tem-se a produção dos "autores" de manuais que aparecem classificados como bibliografia da disciplina de direito constitucional publicada até 1885 (Alecrim, 2011, p. 66). As fontes secundárias apresentam itens classificados de modos diversos. Aparecem como "obras políticas do Brasil Imperial" (Prado, 2012; Neves, 2003). Em outra referência, aparecem como listagem de obras de "História Constitucional" (Rodrigues, 1978, p. 155) e, em uma terceira fonte, o conjunto foi apresentado como "bibliografia" da disciplina de Análise da Constituição do Império (Alecrim, 2011, p. 64). 
Quadro 1

Amostra de manuais de interpretação constitucional da elite brasileira por autor, título, ano, local de publicação e editora (1857-1882)

\begin{tabular}{|c|c|c|c|c|}
\hline Autor & Título & $\begin{array}{c}\text { Ano de } \\
\text { publicação }\end{array}$ & Cidade & Editora \\
\hline $\begin{array}{l}\text { José Antônio } \\
\text { Pimenta Bueno }\end{array}$ & $\begin{array}{c}\text { Direito Público Brasileiro } \\
\text { e Análise da } \\
\text { Constituição do Império }\end{array}$ & 1857 & Rio de Janeiro & $\begin{array}{l}\text { Tip. e Imp. de Jacques } \\
\text { Villeneuve }\end{array}$ \\
\hline $\begin{array}{l}\text { Zacarias de Góis e } \\
\text { Vasconcelos }\end{array}$ & $\begin{array}{c}\text { Da natureza e limites do } \\
\text { poder Moderador }\end{array}$ & $\begin{array}{c}1860 \\
\text { Reedição: } \\
1862\end{array}$ & Rio de Janeiro & $\begin{array}{c}\text { Typographia Universal de } \\
\text { Laemmert }\end{array}$ \\
\hline $\begin{array}{l}\text { José Carlos } \\
\text { Rodrigues }\end{array}$ & $\begin{array}{l}\text { Constituição Política do } \\
\text { Império do Brasil - } \\
\text { seguida do Ato } \\
\text { Adicional, da Lei de sua } \\
\text { Interpretação e de } \\
\text { outras. (Tipo de obra: } \\
\text { "Constituição Anotada", } \\
\text { faz comentários aos } \\
\text { dispositivos) }\end{array}$ & 1863 & Rio de Janeiro & $\begin{array}{c}\text { Ed. Eduardo \& Henrique } \\
\text { Laemmert }\end{array}$ \\
\hline $\begin{array}{l}\text { Brás Florentino } \\
\text { Henriques de Sousa }\end{array}$ & $\begin{array}{l}\text { O Poder Moderador. } \\
\text { Ensaio de Direito } \\
\text { Constitucional }\end{array}$ & 1864 & Recife & Tip. Universal \\
\hline $\begin{array}{l}\text { José Pedreira } \\
\text { França Júnior }\end{array}$ & $\begin{array}{c}\text { A Organização dos } \\
\text { Poderes Constitucionais } \\
\text { nas Monarquias } \\
\text { Representativas }\end{array}$ & 1865 & Bahia & Não identificado \\
\hline $\begin{array}{l}\text { José Maria Corrêa } \\
\text { de Sá e Benevides }\end{array}$ & $\begin{array}{c}\text { O art. } 6^{\circ} \text { da } \\
\text { Constituição é } \\
\text { constitucional? } \\
\text { Analyse da Constituição } \\
\text { Política do Império do } \\
\text { Brazil }\end{array}$ & $\begin{array}{l}1865 \\
1870\end{array}$ & $\begin{array}{l}\text { São Paulo } \\
\text { São Paulo }\end{array}$ & $\begin{array}{l}\text { Não identificado } \\
\text { Não identificado }\end{array}$ \\
\hline José de Alencar & $\begin{array}{c}\text { Uma Tese } \\
\text { Constitucional. A } \\
\text { Princesa Imperial e o } \\
\text { Príncipe consorte no } \\
\text { Conselho de Estado }\end{array}$ & 1867 & Rio de Janeiro & $\begin{array}{c}\text { Livraria Popular de A.A. da } \\
\text { Cruz Coutinho }\end{array}$ \\
\hline $\begin{array}{l}\text { Joaquim Rodrigues } \\
\text { de Sousa }\end{array}$ & $\begin{array}{c}\text { Análise e Comentário da } \\
\text { Constituição Política do } \\
\text { Império do Brasil ou } \\
\text { Teoria e Prática do } \\
\text { Governo Constitucional } \\
\text { Brasileiro }\end{array}$ & 1867 & $\begin{array}{l}\text { São Luis do } \\
\text { Maranhão }\end{array}$ & Tip. de B. de Matos \\
\hline
\end{tabular}


LUCIANA RODRIGUES PENNA

\begin{tabular}{|c|c|c|c|c|}
\hline Autor & Título & $\begin{array}{c}\text { Ano de } \\
\text { publicação }\end{array}$ & Cidade & Editora \\
\hline $\begin{array}{l}\text { Nicolau Rodrigues } \\
\text { dos Santos França e } \\
\text { Leite }\end{array}$ & $\begin{array}{l}\text { Considerações Práticas } \\
\text { sobre a Constituição do } \\
\text { Império do Brasil }\end{array}$ & 1872 & Rio de Janeiro & Tip. M.A.A. de Aguiar \\
\hline $\begin{array}{l}\text { Policarpo Lopes de } \\
\text { Leão }\end{array}$ & $\begin{array}{l}\text { Considerações sobre a } \\
\text { Constituição Brasileira }\end{array}$ & 1872 & Rio de Janeiro & Não identificado \\
\hline $\begin{array}{l}\text { Joaquim Pires } \\
\text { Machado Portela }\end{array}$ & $\begin{array}{l}\text { Constituição Política do } \\
\text { Império do Brasil } \\
\text { confrontada com outras } \\
\text { Constituições e Anotada }\end{array}$ & 1876 & Rio de Janeiro & Tipografia Nacional \\
\hline Filippe Franco de Sá & $\begin{array}{c}\text { A Reforma da } \\
\text { Constituição. Estudo de } \\
\text { História Pátria e Direito } \\
\text { Constitucional. } \\
\text { (Sumário: Alterações } \\
\text { desejáveis na } \\
\text { Constituição do Império. } \\
\text { Limitação dos poderes } \\
\text { da câmara revisora. } \\
\text { Pode essa Câmara ser } \\
\text { dissolvida antes de } \\
\text { decretada a reforma? } \\
\text { Discurso proferido na } \\
\text { Câmara dos Deputados, } \\
\text { a } 20 \text { de maio de 1879) }\end{array}$ & 1880 & Rio de Janeiro & Tipografia Nacional \\
\hline $\begin{array}{l}\text { Hermenegildo } \\
\text { Militão de Almeida }\end{array}$ & $\begin{array}{c}\text { Estudo de algumas } \\
\text { questões constitucionais }\end{array}$ & 1880 & Rio de Janeiro & Tip. do Cruzeiro \\
\hline $\begin{array}{l}\text { Manuel Godofredo } \\
\text { de Alencastro } \\
\text { Autran }\end{array}$ & $\begin{array}{c}\text { Constituição Política do } \\
\text { Império do Brasil } \\
\text { Comentada }\end{array}$ & 1881 & Rio de Janeiro & Ed. H. Laemmert \\
\hline $\begin{array}{l}\text { Paulino José Soares } \\
\text { de Sousa }\end{array}$ & $\begin{array}{c}\text { Ensaio sobre o Direito } \\
\text { Administrativo }\end{array}$ & 1862 & Rio de Janeiro & Tipografia Nacional \\
\hline $\begin{array}{l}\text { Pedro Autran da } \\
\text { Mata Albuquerque }\end{array}$ & $\begin{array}{c}\text { Direito Público Positivo } \\
\text { Brasileiro ( } 2^{\mathrm{a}} \text { ed.) }\end{array}$ & 1882 & Rio de Janeiro & Ed. H. Laemmert \\
\hline
\end{tabular}

Fonte: Elaboração própria com base em sítio do Centro de Documentação do Pensamento Brasileiro (CDPB) (disponível em: <http://www.cdpb.org.br/>; acesso em: 30 ago. 2013), Alecrim (2011), Blake (1899), Dutra (2004), Neves (2003), Prado (2012) e os manuais dos autores.

Reitera-se que o conjunto de dados sobre as publicações e sobre o grupo de autores foi composto a partir do cotejo de referências bibliográficas variadas sobre a 
produção intelectual das elites políticas imperiais, adotando-se como critério de filtragem da coleta a identificação da publicação como "obra jurídica". Dentre as obras identificadas, foram selecionadas as pertinentes ao direito público e ao direito público e constitucional, lançadas durante o período de 1857 a 1888 (Alecrim, 2011; Dutra, 2004; Neves, 2003; Prado, 2012; Blake, 1899).

O maior desafio da pesquisa empírica consistiu em extrair dados sobre a orientação política presente no manual, uma vez que a análise de conteúdo dos textos se depara com a escassez de itens disponíveis para consulta, sejam reeditados por meio impresso ou digitalizados (acessíveis em meio eletrônico). Além disso, registra-se a raridade de informações específicas sobre a vinculação político-partidária ao se analisar as biografias de juristas, possivelmente, em razão do imperativo de imparcialidade e universalidade que pesa sobre o discurso jurídico, embora significativa fração desses agentes tenha atuado diretamente em altas esferas da burocracia e da política imperiais. Desse modo, recorreuse, subsidiariamente, às fontes biográficas e de informações sobre a vida partidária no cenário imperial, buscando dados que indicassem incidência de atividade políticopartidária. Saliente-se que, na qualidade de amostra, as informações não pretendem ser exaustivas, mas fornecer elementos e pistas para a análise de um conjunto representativo do padrão de ação política da elite imperial que atuou na condição de constitucionalista, indicando a relação de seus manuais de interpretação constitucional com os embates políticos do Segundo Reinado.

Com esse objetivo, foram rastreadas 16 publicações lançadas pelo grupo que compõe a elite brasileira dos constitucionalistas do Segundo Reinado. Desse conjunto, o primeiro aspecto que se pode extrair é quanto à proeminência da centralização da produção doutrinária na sede da Corte, o Rio de Janeiro, o que aponta um forte vínculo entre doutrina jurídica e poder estatal. No universo de 16 manuais, 12 foram lançados no Rio de Janeiro, sendo apenas 1 no Recife (a outra cidade que sediava um Curso Jurídico, a partir de 1854), 1 na Bahia, 2 em São Paulo e 1 em São Luís do Maranhão. Apenas uma obra não está identificada quanto à cidade de publicação. Por contrastar com a diversidade de origem geográfica dos autores, esses dados indicam que o objetivo da produção de doutrina constitucional foi predominantemente político, mais do que científico, pela estreita ligação desse publicismo com as carreiras profissionais e políticas dos agentes, situadas no Rio de Janeiro, pois os manuais não foram lançados predominantemente nas duas cidades onde nesse momento funcionavam os cursos jurídicos imperiais: Recife e São Paulo.

Nas condições da sociedade imperial, esse fator indica que as referidas obras foram direcionadas a um público que não era constituído, necessariamente e imediatamente, pelos estudantes e professores de direito. Ao contrário, como a Corte era o centro político do país, esse aspecto assinala que a eufemização de questões políticas reconstruídas como "problemas constitucionais" vinculava-se muito mais às disputas intraelites, aos "olhares estrangeiros" e às demandas de uma legitimação "técnica" e "teórica" para as reivindicações das frações rurais e urbanas da Corte e do Sudeste cafeeiro, representadas 
por esses políticos-bacharéis. Pela localização das publicações é possível verificar a posição periférica das outras províncias, como Pernambuco, Bahia, Maranhão. Desse modo, verifica-se que os constitucionalistas desempenharam um papel como agentes encarregados das estratégias de sustentação e reforma do regime imperial no Segundo Reinado, em que o investimento nesse tipo de recurso de poder simbólico foi realizado pelos políticos-bacharéis e professores, tanto os de orientação conservadora, os saquaremas, monarquistas, católicos, centralistas, defensores do Poder Moderador e da manutenção do modelo político e social hierarquizado (voto desigual, restrição ao acesso à participação política) quanto políticos, professores e jornalistas identificados com o perfil liberal ou luzia, de índole mais descentralista e reformista. O liberal Franco de Sá, por exemplo, ilustra um caso de autor manual, publicado em 1880, voltado à prescrição de uma reforma no texto da Constituição.

A partir da descoberta da presença de políticos-bacharéis conservadores e liberais na amostra, constatou-se também que os agentes do núcleo da política saquarema e da contestação luzia estiveram atuando no plano doutrinário via constitucionalismo. Logo, se é correto afirmar, por exemplo, que Pimenta Bueno, apontado como um dos protagonistas da dominação saquarema, foi, simultaneamente, o "jurista da Coroa", também é verdadeiro que não esteve sozinho na disputa política pela consolidação do sentido legítimo da "regra constitucional". Outro aspecto relevante extraído da amostra indica que os 16 manuais foram publicados ao longo de 25 anos, isto é, entre 1857 e 1882 . Essa quantidade representa uma média de publicação de um livro de "interpretação constitucional" a cada dois anos em um país que só possuía dois cursos de direito. Pela comparação com a amostra de manuais de "interpretação constitucional" publicados pela elite "coimbrã" durante o Primeiro Reinado e Período Regencial, cujo total foi de 12 obras publicadas em 30 anos (entre 1824 e 1854), constata-se uma significativa continuidade e, mesmo, um aumento no volume de mobilização desse recurso pela elite política identificada como os "consolidadores" do regime imperial.

Quadro 2

Comparativo de investimento das elites coimbrã e brasileira no constitucionalismo

\begin{tabular}{|l|c|c|c|}
\hline Geração & $\begin{array}{c}\text { Número de } \\
\text { indivíduos }\end{array}$ & Período & $\begin{array}{c}\text { Quantidade de obras } \\
\text { jurídicas }\end{array}$ \\
\hline Coimbrãos & 8 & $1824-1854$ (30 anos) & 12 \\
\hline Brasileiros & 16 & $1857-1882$ (25 anos) & 16 \\
\hline
\end{tabular}

Fonte: Elaboração própria com base em: sítio do Centro de Documentação do Pensamento Brasileiro (CDPB) (disponível em: <http://www.cdpb.org.br/>; acesso em: 30 ago. 2013), Alecrim (2011), Blake (1899), Dutra (2004), Neves (2003), Prado (2012).

Os números acima indicam a duplicação no círculo dos "intérpretes da Constituição" durante a vigência do Império, acompanhando a urbanização e a formação de bacharéis a 
partir das escolas brasileiras. Esses dados também indicam que a elite imperial brasileira refletia um apego ao ideal da Constituição, representando sua própria "missão" como a de dar continuidade à tarefa de erguer o edifício político nacional, de formato monárquico, dentro do molde "constitucional", tomando a apropriação da dimensão jurídico-doutrinária como estratégia eficaz dessa "missão política". A linha temporal da intervenção política através de manuais jurídicos de direito público e constitucional demonstra que esse fenômeno pode ser tomado como a continuidade de um esforço coletivo das elites letradas imperiais, ou seja, o empenho de um grupo de agentes da elite política imperial, que, identificados com um ou outro dos campos político-partidários existentes, investiu na mobilização da "Constituição" como forma "neutra", "imparcial", "científica", "técnica" e "asséptica" de intervenção política. E, nesses atributos da teorização jurídica, a elite encontrou um meio de preservação de seu estatuto político.

Com relação à presença de indivíduos situados na alta esfera política do Império, oriundos das academias de direito de São Paulo e Olinda (Recife), encontraram-se tanto nomes de conservadores quanto de liberais, como: Braz Florentino Henriques de Sousa, José Antônio Pimenta Bueno, José Maria Correia de Sá e Benevides, Joaquim Rodrigues de Sousa, Paulino Soares, Zacharias de Góis e Vasconcelos e Filippe Franco de Sá. Por isso, detecta-se a característica da ambivalência de tipos ideais: a posição do "político", de decidir a ordem, aparece articulada com o papel do "jurista", isto é, de "interpretar" a ordem. Esse atributo de dupla legitimidade expressou-se na forma de mobilização política dos saberes jurídicos como direito público e constitucional, indicando a necessidade de eufemização dos posicionamentos sobre o regime imperial, a partir do obscurecimento do engajamento político propiciado pela fala autorizada, pedagógica, científica e neutra dos manuais de direito.

O domínio das denominadas "letras jurídicas", especialmente aquele engendrado como publicismo, pode ser abordado, nessa linha, como uma ferramenta empregada na composição de uma alta elite intelectual nacional, habilitada para desempenhar a política com "P" maiúsculo8. Um outro aspecto a ser apontado a partir da amostra diz respeito à nomenclatura utilizada pelos agentes para o título das obras. Pode-se observar que o emprego de títulos generalistas predomina no caso dos manuais dos políticos "conservadores", como: Comentários à Constituição do Império, Lições de direito público e constitucional, Direito público brasileiro, Constituição comentada, Direito público e análise da Constituição etc. Esse formato indica a opção pela generalidade e universalidade com vistas a dotar a obra de uma aura de amplitude temática e de desinteresse em

\footnotetext{
8 Dessa forma, a lógica de eufemização de posicionamentos políticos não pode ser explicada unicamente com base na necessidade de responder às questões da política interna, regional e local, mas, sobretudo, como mecanismo correspondente àquilo que Joaquim Nabuco denominava de política com "P" maiúsculo, ou seja, o conjunto de tarefas que estavam a cargo de uma alta elite, uma elite dentro da elite. Esse papel cumpriria, portanto, àqueles poucos agentes que assumissem a tarefa da "grande política", atuando na esfera das instituições nacionais, visando a sustentar a construção e a preservação da imagem de "nação civilizada" que as elites políticas brasileiras desejavam apresentar aos países "civilizados", especialmente, aos europeus (Grijó, 2005, p. 70).
} 
questões pontuais, mais identificáveis como "problemas políticos". Essa estratégia de linguagem geral, neutralista, objetiva, abstrata e impessoal aparece em maior número nos manuais de autoria dos saquaremas, porquanto os mais afeitos ao discurso de Estado.

Constata-se, assim, uma sutil, mas importante diferença das produções saquaremas em relação aos manuais dos "liberais", estes menos adeptos do formato generalista e mais voltados às discussões pontuais, isto é, reformistas. Ao contrário dos conservadores, os liberais, em muitos casos, restringiam o debate a pontos específicos. Essa característica apareceu no manual do Conselheiro Zacarias, nome central do Partido Luzia, direcionado a tratar apenas da questão do Poder Moderador. Mais afeito ao debate pontual, em função de seus contorcionismos retóricos, afirmou-se mesmo que Zacarias era dado a verdadeiras "cambalhotas argumentativas" (Ambrosini e Ferreira, 2010, p. 145). Tais distinções nos livros não refletiriam, portanto, mera diferença de talentos individuais ou opções retóricas, mas resultariam das distintas posições políticas ocupadas pelos agentes no campo do poder. O manual de Felippe Franco de Sá também ilustra um caso de reformismo liberal, com abordagem doutrinária de questão específica, nesse caso, indicando pontos a serem objeto de "Reforma Constitucional".

Quadro 3

Amostra de dados biográficos e de percurso dos autores de obras de direito público e constitucional do Segundo Reinado por nome, ano e local de nascimento, ano e local de graduação

\begin{tabular}{|c|c|c|c|}
\hline Nome & $\begin{array}{c}\text { Ano de } \\
\text { nascimento }\end{array}$ & $\begin{array}{c}\text { Local de } \\
\text { nascimento }\end{array}$ & Ano e local de graduação \\
\hline $\begin{array}{l}\text { José Antônio Pimenta } \\
\text { Bueno }\end{array}$ & 1803 & Santos, SP & 1832, Faculdade de Direito de São Paulo \\
\hline $\begin{array}{l}\text { Zacarias de Góis e } \\
\text { Vasconcelos }\end{array}$ & 1815 & Bahia & 1837, Academia de Direito de Olinda \\
\hline $\begin{array}{l}\text { José Carlos } \\
\text { Rodrigues }\end{array}$ & 1844 & Cantagalo, RJ & Não identificado \\
\hline $\begin{array}{l}\text { Brás Florentino } \\
\text { Henriques de Sousa }\end{array}$ & 1825 & Paraíba & 1850, Faculdade de Direito do Recife. \\
\hline $\begin{array}{l}\text { José Pedreira França } \\
\text { Júnior }\end{array}$ & $\begin{array}{c}\text { Não } \\
\text { identificado }\end{array}$ & Não identificado & Não identificado \\
\hline $\begin{array}{l}\text { José Maria Correia de } \\
\text { Sá e Benevides }\end{array}$ & 1833 & $\begin{array}{l}\text { Campos dos } \\
\text { Goytacazes, SP }\end{array}$ & $\begin{array}{l}\text { Bacharel em Letras pelo Colégio Pedro II (Rio } \\
\text { de Janeiro). Doutor em ciências sociais e } \\
\text { jurídicas pela Faculdade de Direito de São Paulo }\end{array}$ \\
\hline José de Alencar & 1829 & Mecejana, CE & 1850, Faculdade de Direito de São Paulo. \\
\hline $\begin{array}{l}\text { Joaquim Rodrigues } \\
\text { de Sousa }\end{array}$ & $\begin{array}{c}\text { Não } \\
\text { identificado }\end{array}$ & Não identificado & Não identificado \\
\hline $\begin{array}{l}\text { Nicolau Rodrigues } \\
\text { dos Santos França e } \\
\text { Leite }\end{array}$ & $\begin{array}{c}\text { Não } \\
\text { identificado }\end{array}$ & Não identificado & Não identificado \\
\hline
\end{tabular}


O PUBLICISMO E A POLÍTICA CONSERVADORA DO BRASIL NO SÉCULO XIX

\begin{tabular}{|l|c|c|c|}
\hline Nome & $\begin{array}{c}\text { Ano de } \\
\text { nascimento }\end{array}$ & $\begin{array}{c}\text { Local de } \\
\text { nascimento }\end{array}$ & Ano e local de graduação \\
\hline $\begin{array}{l}\text { Policarpo Lopes de } \\
\text { Leão }\end{array}$ & 1814 & Bahia & Não identificado \\
\hline $\begin{array}{l}\text { Joaquim Pires } \\
\text { Machado Portela }\end{array}$ & 1827 & Recife, PE & Não identificado \\
\hline Filipe Franco de Sá & 1841 & Alcântara, MA & Não identificado \\
\hline $\begin{array}{l}\text { Hermenegildo Militão } \\
\text { de Almeida }\end{array}$ & $\begin{array}{l}\text { Não } \\
\text { identificado }\end{array}$ & Não identificado & 1869, não identificado de Direito do Recife. \\
\hline $\begin{array}{l}\text { Manuel Godofredo de } \\
\text { Alencastro Autran }\end{array}$ & 1848 & Recife, PE & Iniciou o curso em Coimbra (1823) \\
\hline $\begin{array}{l}\text { Paulino José Soares } \\
\text { de Sousa } \\
\text { (Visconde do } \\
\text { Uruguai) }\end{array}$ & 1807 & Paris, França & Graduou-se em 1831 na Faculdade de Direito \\
\hline
\end{tabular}

Fonte: Elaboração própria com base em: Alecrim (2011), Blake (1899), Dutra (2004), Prado (2012). Sítio do Portal do Supremo Tribunal Federal (disponível em: <www.stfjus.br>, acesso em: 27 ago. 2013); sítio do Centro de Documentação do Pensamento Brasileiro (disponível em: <www.cdpb.org.br>, acesso: em 27 ago. 2013); e <http://www.ebiografias.net/jose_alencar/>, acesso em: 27 ago. 2013; <http://familytreemaker.genealogy.com/users/p/o/Sergio-RPorto-Rio-de-Janeiro/FILE/0004text.txt>, $\quad$ acesso em: $29 \quad$ out. <https://www25.senado.leg.br/web/senadores/senador/-/perfil/1629>, acesso em: 15 jul. 2019.

Nesse sentido, é preciso salientar que, no contexto imperial, o discurso constitucional que emergiu não esteve nem exclusivamente ligado ao mundo acadêmico, nem completamente apartado dele, mas permaneceu fortemente vinculado às tomadas de posições políticas. Por essa razão, é necessário salientar que, no caso do contexto monárquico brasileiro, o universo acadêmico e a questão do exercício da docência em direito constitucional não podem ser tomados como os únicos critérios para explicar o surgimento da categoria de intérprete da Constituição. O Brasil Império refletiu a multifuncionalidade da elite letrada, sendo que os manualistas nunca foram exclusivamente professores (Adorno, 1988, p. 139).

Infere-se da amostra que já se tratava de um grupo formado no Brasil, representando, por isso, uma elite de letrados "brasileira". Pelo menos cinco agentes estudaram nas escolas nacionais de São Paulo ou Olinda/Recife (Pernambuco). Já o nascimento em províncias diversas aponta a diversificação da origem regional, indicando a mobilidade ou circulação dos agentes do grupo. Por fim, um dos aspectos mais relevantes da pesquisa empírica consiste na coleta de dados de percurso político e profissional dos juristas, de modo a verificar se se tratava de um grupo mais diversificado ou de uma "nobreza de Estado" (Bourdieu, 2013). A partir do Quadro 4, pode se verificar os dados de percurso, como modo de identificar a existência de padrão de inserção docente, política e/ou burocrática: 


\section{Quadro 4 \\ Inserção profissional, política e administrativa da amostra dos intérpretes da Constituição no Segundo Reinado}

\begin{tabular}{|c|c|}
\hline Nome & Cargos burocráticos e/ou políticos \\
\hline $\begin{array}{l}\text { José Antônio } \\
\text { Pimenta Bueno }\end{array}$ & $\begin{array}{l}\text { Presidente de província do Mato Grosso. } \\
\text { Presidente da província do Rio Grande do Sul. } \\
\text { Ministro do Gabinete Imperial. } \\
\text { Presidente do Conselho de Ministros. } \\
\text { Senador do Império. }\end{array}$ \\
\hline $\begin{array}{l}\text { Zacarias de Góis e } \\
\text { Vasconcelos }\end{array}$ & $\begin{array}{c}\text { Inicia a carreira política no campo conservador em 1840, como deputado na Assembleia da } \\
\text { Bahia; em } 1850 \text { ingressa na Câmara dos Deputados. } \\
1860 \text { - Ruptura com o Partido Conservador e inserção no Partido Liberal. } \\
\text { Lente da Academia Jurídica de Olinda. } \\
\text { Líder do Partido Liberal; três vezes presidente do Conselho de Ministros (1862-1864). } \\
\text { Senador do Império. } \\
\text { Título de "Conselheiro" concedido por D. Pedro II. }\end{array}$ \\
\hline $\begin{array}{l}\text { José Carlos } \\
\text { Rodrigues }\end{array}$ & $\begin{array}{c}\text { Fundou com José da Silva Costa, em São Paulo, a Revista Jurídica (1862-1873). Em 1863, } \\
\text { ainda como estudante, publicou Constituição política do Império do Brasil. } \\
\text { No âmbito do jornalismo: diretor e principal redator do Jornal do Comércio. Em Nova York, } \\
\text { publicou dois jornais em português: o Novo Mundo (1870-1979), coadjuvado por Sousa } \\
\text { Andrade, e a Revista Industrial (1878-1879). Em Londres, colaborou no Time e no Financial } \\
\text { News (1882) e negociou o primeiro empréstimo provincial ao Brasil, em favor de São Paulo. } \\
\text { Regressando ao Brasil (1890), comprou o Jornal do Comércio, que dirigiu por } 25 \text { anos. }\end{array}$ \\
\hline $\begin{array}{l}\text { Brás Florentino } \\
\text { Henriques de } \\
\text { Sousa }\end{array}$ & $\begin{array}{l}\text { Nomeado professor na Faculdade de Direito do Recife em 1865; presidente da província do } \\
\text { Maranhão }(1869-1870) .\end{array}$ \\
\hline $\begin{array}{l}\text { José Pedreira } \\
\text { França Júnior }\end{array}$ & Trajeto não identificado. \\
\hline $\begin{array}{l}\text { José Maria Correia } \\
\text { de Sá e Benevides }\end{array}$ & $\begin{array}{l}\text { Foi Presidente das províncias de Minas Gerais, de } 14 \text { de maio de } 1869 \text { a } 26 \text { de maio de } 1870 ; \\
\text { foi presidente de província do Rio de Janeiro, de } 1 \text { de junho a } 27 \text { de outubro de } 1870 \text {; foi } \\
\text { Lente da Faculdade de Direito de São Paulo. } \\
\text { Orientação política: monarquista e conservador. }\end{array}$ \\
\hline José de Alencar & $\begin{array}{c}\text { Romancista. } \\
\text { Em } 1858 \text { abandona o jornalismo para ser chefe da Secretaria do Ministério da Justiça, onde } \\
\text { chega à Consultoria. } \\
\text { Detentor do título de Conselheiro. } \\
\text { Professor de direito mercantil. } \\
\text { Eleito deputado pelo Ceará em 1861, pelo Partido Conservador, sendo reeleito em quatro } \\
\text { legislaturas. } \\
\text { Autor de Iracema. }\end{array}$ \\
\hline $\begin{array}{l}\text { Joaquim } \\
\text { Rodrigues de } \\
\text { Sousa }\end{array}$ & Desembargador. Trajeto não identificado. \\
\hline $\begin{array}{l}\text { Nicolau Rodrigues } \\
\text { dos Santos França } \\
\text { e Leite }\end{array}$ & Trajeto não identificado. \\
\hline $\begin{array}{l}\text { Policarpo Lopes de } \\
\text { Leão }\end{array}$ & $\begin{array}{c}\text { Magistrado. } \\
\text { Desembargador. } \\
\text { Membro do Conselho do Imperador. } \\
\text { Presidente da província do Rio de Janeiro (1863-1864). }\end{array}$ \\
\hline
\end{tabular}




\begin{tabular}{|c|c|}
\hline Nome & Cargos burocráticos e/ou políticos \\
\hline $\begin{array}{l}\text { Joaquim Pires } \\
\text { Machado Portela }\end{array}$ & $\begin{array}{c}\text { Presidente e vice-presidente de províncias. } \\
\text { Deputado-Geral. } \\
\text { Diretor do Arquivo Nacional (1873-1898). }\end{array}$ \\
\hline $\begin{array}{l}\text { Filippe Franco de } \\
\text { Sá }\end{array}$ & $\begin{array}{c}\text { Servidor Público; promotor público. } \\
\text { Magistrado. } \\
\text { Ministro da Guerra. } \\
\text { Ministro dos Estrangeiros. } \\
\text { Ministro do Império. } \\
\text { Deputado-Geral pelo Maranhão (1877-1882). } \\
\text { Senador do Império do Brasil pelo Maranhão (1882-1889). }\end{array}$ \\
\hline $\begin{array}{l}\text { Hermenegildo } \\
\text { Militão de Almeida }\end{array}$ & Professor catedrático da Faculdade Livre de Ciências Jurídicas e Sociais. \\
\hline $\begin{array}{l}\text { Manuel Godofredo } \\
\text { de Alencastro } \\
\text { Autran }\end{array}$ & $\begin{array}{l}\text { Juiz de Direito no Pará. } \\
\text { Jornalista, músico, poeta. }\end{array}$ \\
\hline $\begin{array}{l}\text { Paulino José } \\
\text { Soares de Sousa } \\
\text { (Visconde do } \\
\text { Uruguai) }\end{array}$ & $\begin{array}{c}\text { Magistrado. } \\
\text { Deputado pela província do Rio de Janeiro; presidente de província do Rio de Janeiro (1836- } \\
\text { 1840). } \\
\text { Magistrado e diplomata brasileiro nascido em Paris. } \\
\text { Porta-voz da classe dirigente do Império, líder do grupo fluminense. } \\
\text { Jurista na área do direito público e constitucional. } \\
\text { Integrou a então poderosa oligarquia do Segundo Reinado, o famigerado Triunvirato de } \\
\text { Saquarema, do qual faziam parte, além dele, o Visconde de Itaboraí, Joaquim José Rodrigues } \\
\text { Torres (1802-1872) e o magistrado e político brasileiro Eusébio de Queirós Coutinho Matoso } \\
\text { da Câmara (1812-1868). } \\
\text { Foi um dos idealistas do Partido Conservador. } \\
\text { Ministro da Justiça em } 1840 \text { e 1841-1843, ocasião em que restaurou o Conselho de Estado e } \\
\text { reformou o Código do Processo Criminal. } \\
\text { Ministro dos Negócios Estrangeiros (1843-1844); } \\
\text { Senador do Império (1849) na bancada do Partido Conservador. } \\
\text { Ministro de Negócios Estrangeiros (1849-1853) que antecipou, por meio de atos e gestões } \\
\text { diplomáticas, a campanha militar que culminaria na queda do caudilho argentino Juan } \\
\text { Manuel de Rosas, na campanha militar de Monte Caseros (1852). } \\
\text { Desembargador da Relação da Corte (1852). } \\
\text { Conselheiro de Estado (1853) e recebeu no ano seguinte o título de Visconde do Uruguai. } \\
\text { Vai a Paris (1855) como enviado extraordinário para tratar dos limites do Império com a } \\
\text { Guiana Francesa, a chamada Questão do Oiapoque. } \\
\text { Ministro do Supremo Tribunal de Justiça (1857). } \\
\text { Publicou vários trabalhos de cunho parlamentar, jurídico, administrativo e político, entre eles } \\
\text { Ensaio sobre o direito administrativo (1862) e Estudo prático sobre a administração das } \\
\text { províncias (1865). } \\
\text { Morreu no Rio de Janeiro, então capital do Império, aos } 58 \text { anos. }\end{array}$ \\
\hline
\end{tabular}

Fonte: Elaboração própria com base em: Alecrim (2011), Blake (1899), Dutra (2004), Prado (2012), Simões (1983), sítio do Portal do Supremo Tribunal Federal (<www.stfjus.br>; acesso em: 27 ago. 2013), sítio do Centro de Documentação do Pensamento Brasileiro (disponível em: <www.cdpb.org.br>; acesso em: 27 ago. 2013), <http://www.ebiografias.net/jose_alencar/> (acesso em: 27 ago. 2013), <http://familytreemaker.genealogy.com/users/p/o/Sergio-RPorto-Rio-de-Janeiro/FILE/0004text.txt> (acesso em: 29 out. 2013).

Com base nas informações levantadas, verifica-se, em regra, a longa inserção política e burocrática desses juristas, apontando a combinação entre posicionamentos políticos, engajamento partidário, experiência na magistratura e na alta burocracia e largo saber jurídico. Destaca-se nos percursos de tais agentes a incidência comum dessas 
características, o que só pode ser capturado em uma análise prosopográfica. Enfatiza-se que trajetos individuais das elites políticas também foram abordados em trabalhos de história das ideias políticas (Saldanha, 2001), no entanto, de modo diverso da presente proposta, vendo-os como "protagonistas" da vida política ou jurídica imperial, o que conduz à fixação na noção de "grandes personagens", desprezando a dimensão coletiva do fenômeno social ou político. Essa percepção foi detectada em algumas abordagens biográficas sobre casos como o de José Antônio Pimenta Bueno, representado como "o publicista do Império" (Alecrim, 2011; Carvalho, 2006). Essa opção em enfatizar a atuação de um único indivíduo personaliza a análise, uma vez que não o insere em um conjunto que, na realidade, foi bem mais amplo. Negligencia-se, com isso, o caráter coletivo da ação impresso nas estratégias de luta política.

A representação como "o publicista do Império", dessa forma, contribui para mitificar o agente, dissimulando as condições sociais em que José Antônio Pimenta Bueno atuou como jurista destacado: ele publicou sua obra quando já era um político de prestígio, inserido nas altas esferas do poder e fortemente vinculado ao segundo imperador. Como político, foi atuante na vida política imperial, vinculado à promoção de grandes reformas a partir de 1860-1870. Pimenta Bueno ilustra, então, o caso de um político-jurista fortemente identificado com o Partido Saquarema. Seu percurso, que aponta uma origem social modesta, menino que não nascera em família abastada, mas mediana, na cidade de Santos (SP), indica um trajeto de ascensão social a partir da formação acadêmica em direito e da proteção de um político influente. Dessa forma, sua trajetória apresenta muitos elementos comuns com os percursos da elite imperial, característicos dos políticosbacharéis do Segundo Reinado, como: a graduação em direito, a reconversão de campo político (do Liberal para o Conservador ou vice-versa), a condição de tornar-se, primeiramente, magistrado, para poder ingressar na vida política e o apadrinhamento de um político importante, no caso líder liberal Martim Francisco Ribeiro de Andrada (Kugelmas, 2002, p. 20). O que diferencia o trajeto de Pimenta Bueno no grupo de constitucionalistas é que ele representa um caso de "direção política", pois ocupou cargos políticos no topo do Estado, como os postos de chefe do Conselho de Ministros, senador e conselheiro de Estado (Nogueira e Firmo, 1973, p. 109) e apresentou os projetos de lei abolicionistas de 1870 (Kugelmas, 2002, p. 26).

Outro fator importante a ser enfatizado sobre Pimenta Bueno diz respeito ao reconhecimento conquistado pela proximidade com a pessoa do monarca, o que é indicado por sua imagem de "conselheiro jurídico privado do Imperador" (Alecrim, 2011, p. 68). A repercussão desse vínculo sobre sua produção doutrinária é nítida, tendo seu manual Direito público brasileiro e análise da Constituição do Império (1857) figurado como "livro de cabeceira do Imperador" (Kugelmas, 2002). Porém, para aprofundar a relação de sua elaboração teórica com a inserção político-partidária, é necessário comparar a produção com a trajetória de José Antônio Pimenta Bueno.

Detecta-se, pelos dados obtidos, que Pimenta Bueno ocupou diversos cargos 
eletivos - como deputado (1845-1847) e como senador (1853-1878) - e também no Poder Executivo. Como sua inserção política pesava na construção dos conceitos jurídicos? A atuação política e administrativa do saquarema Marquês de São Vicente, passando por diversos postos de indicação e nomeação política, especialmente no domínio do Poder Executivo, expõe a forte proximidade com o "círculo dos mais próximos" do imperador D. Pedro II. Essa pode ser uma explicação para o fato de centrar-se no Direito público brasileiro e análise da Constituição do Império, não somente como forma de garantir a impessoalidade da análise do "intérprete", mas de não enfatizar a existência de um direito público universal, o que the demandaria estender o abrigo constitucional às monarquias descentralizadas, aos regimes em que o monarca fosse apenas chefe de Estado e mesmo aos regimes republicanos. O saquarema, permanecendo focado na Constituição de 1824, adotou no título da obra uma verdadeira "taxonomia" (Kugelmas, 2002, p. 35).

A análise de conteúdo do manual indica que José Antônio Pimenta Bueno empreendeu comentário exaustivo dos dispositivos da Constituição de 1824, inclusive sobre as regras reformadas pelo Ato Adicional de 1834 e pela Lei de Interpretação deste, de 1841 . Porém, sua remissão ao surgimento do Ato de 1834 , constante da "seção $2^{a "}$ da obra, omite que se tratava do contexto de luta política entre "liberais" e "conservadores" e que o Ato foi consequência da aprovação parcial do projeto liberal, ou seja, de que foi uma reforma política de caráter "liberal" e contestatório do sistema centralizado, restituído em $1841^{9}$. Constata-se, assim, que o "conservador moderado" São Vicente empregou estratégias de "edição" do passado histórico, não problematizando a origem outorgada da Constituição, nem os sentidos de resistência, contestação e "reação" contidos nas "Reformas Constitucionais" das décadas de 1830 e 1840. O título do manual de Pimenta Bueno possui em parte uma representação ambivalente, sendo o direito público a encarnação da "ciência", o domínio da teoria jurídica como conhecimento acumulado pela humanidade, um saber "universal", domínio da elite letrada. Já a análise da Constituição representava a inteligibilidade do sistema político vigente, traduzido aos leigos pela pena dos "doutos" ou "publicistas". Desse modo, o manejo da linguagem e o uso do sentido de cientificidade e generalidade emprestado à "interpretação constitucional" por Pimenta Bueno refletem a sua posição na hierarquia social e política, repercutindo como apologia da "Constituição"10.

\footnotetext{
9 Pimenta Bueno explicava, ao tratar na "seção 2a" das "atribuições da Assembleia Geral, conservadora da forma de governo e da ordem política", que a aprovação do Ato Adicional era a entrada em vigor de uma "lei promulgada em 12 de agosto de 1834 que fez adições e alterações à Constituição de 1824. Entre outras determinações, suspendeu o exercício do poder Moderador durante a Regência, suprimiu o Conselho de Estado e criou Assembleias Provinciais com maiores poderes em substituição aos antigos Conselhos Gerais" (Kugelmas, 2002, p. 121).

10 Mas o problema da distinção entre direito público e Constituição é resolvido pela "síntese" ou identificação de ambos no caso brasileiro. Segundo Pimenta Bueno: "Nosso Direito Público positivo é a sábia Constituição política que rege o Império: cada um de seus belos artigos é um complexo resumido dos mais luminosos princípios do Direito Público filosófico ou racional. Procuraremos, pois, desenvolvê-los; não separaremos um do outro; aquele é a nossa lei pública, este é a fonte esclarecida, de que ela foi derivada" (Pimenta Bueno apud Kugelmas, 2002, p. 58).
} 
Dedicando o seu manual aos herdeiros da elite, eufemizados como "mocidade estudiosa que em breve terá de governar o Estado", Pimenta Bueno demonstra sua erudição ao oferecer, no início da obra, uma lista de autores e fontes do direito constitucional que inclui 38 nomes de autores, a maioria estrangeiros, sendo que em torno de 31 eram franceses (Kugelmas, 2002, p. 74). Por fim, na defesa da ordem vigente, Pimenta Bueno utiliza no manual a mesma denominação que era empregada na disciplina de direito constitucional e que foi mantida ao longo do Império: Análise da Constituição do Império. Como anteriormente referido, a disputa entre conservadores e liberais repercutiu sobre a academia jurídica, traduzida na concorrência entre o estudo do direito público, de tom "universal", portanto, comparativo com outros sistemas de dominação, e a análise da Constituição do Império, como reprodução dos dispositivos constantes do texto em vigor, já reformado em 1841, estratégia da elite "conservadora" para reproduzir o teor da "Constituição" como a referência do pensamento e da prática política das elites.

Também ilustrativo da combinação entre elevada formação intelectual e interesse no uso do publicismo para fins políticos é o caso do líder saquarema Paulino José Soares de Sousa, o Visconde do Uruguai. Seu manual de doutrina Ensaio sobre o direito administrativo, originalmente em dois volumes, publicado pela Tipografia Nacional na cidade do Rio de Janeiro em 1862, alcançou duas edições ${ }^{11}$. Paulino Soares de Sousa foi um dos mais destacados políticos conservadores do período do Império, cuja biografia revela a precoce mobilização do saber jurídico e do capital de relações políticas para o ingresso na carreira pública. O manual de Paulino Soares de Sousa se enquadra dentro da característica de autoria de um agente com inserção no círculo mais estreito do poder e multiposicionado na elite, com investimento na mobilização do domínio do saber jurídico. Sua produção está veiculada como integrante do universo disciplinar do direito administrativo, mas ele não deixou de manifestar sua articulação com o discurso do direito constitucional, a relação de subordinação entre ambos os saberes e a preeminência do direito constitucional sobre o direito administrativo, repercutindo a dominação da centralização política sobre a estruturação da esfera burocrática.

Já um caso representativo de uso político liberal ou luzia extraído da amostra está na obra Da natureza e limites do Poder Moderador. O manual, de autoria do líder político liberal Conselheiro Zacarias de Góis e Vasconcelos, retrata a sua alta inserção política, sobretudo, parlamentar, e a atuação no Poder Executivo e na docência em direito no curso de Olinda. A instrumentalização do saber jurídico para fins políticos é tão explícita, que, no manual publicado em 1860 e reeditado em 1862, Zacarias expressamente "responde" às

\footnotetext{
11 Tal habilidade de teórico pode ser considerada central no percurso do agente: "Paulino José Soares de Souza, o Visconde do Uruguai, foi o principal teórico da corrente conservadora do Segundo Império e um dos principais construtores das instituições políticas que perduraram até a queda do regime. Não foi filósofo. Seu pensamento e sua ação cingiram-se ao campo do direito e da política. Não obstante, em várias passagens de sua obra maior, publicada em 1862, o Ensaio Sobre o Direito Administrativo, inspirada no que ele denomina de 'ecletismo esclarecido', encontra-se um pensamento moral muito semelhante ao que será eventualmente sistematizado por Paul Janet, quando o filósofo eclético francês publicou, em 1874, a obra La Morale" (Rodrigues, 2011, p. 139).
} 
críticas dos adversários políticos e se contrapõe ao entendimento dos conservadores, sobretudo de José Antônio Pimenta Bueno e de Paulino José Soares de Sousa (Oliveira, 2002, p. 30). Saliente-se que Zacarias não era um liberal "exaltado" ou "radical", mas um defensor da monarquia representativa que não se contrapunha à existência do Poder Moderador, mas apenas exigindo a responsabilidade dos ministros de Estado pelos atos do imperador.

Se comparado com o percurso de Pimenta Bueno, o trajeto do Conselheiro Zacarias apresenta a inversão de ter iniciado na carreira política no campo conservador, pelo apadrinhamento do político conservador Francisco Gonçalves Martins, futuro Visconde de São Lourenço (Oliveira, 2002, p. 10), e após, em 1860, encaminhar-se para o campo Liberal. Com larga experiência política e administrativa, uma vez que foi presidente de província do Piauí e de Sergipe, em 1850 passa a integrar a Câmara dos Deputados, iniciando uma carreira política nacional que lhe permitiria participar de quatro ministérios e chegar à presidência do Conselho de Ministros por três vezes, entre 1862 e 1864, e à posição de senador (p. 10). Caracteres como a inserção oposicionista, a postura menos impessoal, por ser "independente em relação ao ponto de vista partidário e intransigente em suas conviç̧ões doutrinárias", a "falta de impersonalidade" (Oliveira, 2002, p. 21) e a "capacidade de se tornar crítico mesmo das atuações dos próprios colegas de Partido", constituem disposições que o distanciavam do perfil desinteressado, "científico" e neutralista dos manuais de doutrina jurídica, mais bem manejados pelos políticos conservadores, como Pimenta Bueno e Paulino de Sousa.

O título e o conteúdo de seu livro Da natureza e dos limites do Poder Moderador não o apresentam no formato tradicional de um extenso manual de direito público e constitucional, mas, nas palavras do próprio Zacarias, como um "opúsculo", "destinado a apenas ser, como em verdade foi, distribuído por amigos e conhecidos" (Oliveira, 2002, p. 63). Esse aspecto reflete, em certa medida, a relação entre a posição do agente e a sua produção teórica, atestando seu menor alcance. Destaca-se que, na segunda edição da obra, em 1862, Zacarias sublinhou, na apresentação do texto ao leitor, que a justificativa de sua reedição se devia à necessidade de responder ao trabalho do Visconde do Uruguai. Essa disposição repercute no livro a sua posição dominada na esfera política, ainda que fosse inserido nas mais altas esferas, pois restringiu sua exposição, explorando apenas uma questão: a responsabilidade dos ministros pelos atos do Poder Moderador, tese que reivindicava a prestação de contas do Poder Executivo perante o Poder Legislativo. Para tratar de tema único, não formulou amplo e sistematizado "manual" comentando os temas da "Constituição".

Por fim, o que é possível deduzir a partir do conjunto de dados obtidos e da análise de conteúdo de alguns casos ilustrativos é a nítida associação entre expertise jurídica, experiência burocrática e capital político como condições para obter o estatuto de constitucionalista. O constitucionalismo do Segundo Reinado foi obra de uma fração da elite. Isso explica por que a constitucionalização do debate político esteve apenas 
parcialmente vinculada à atuação docente. Em contraste, tem-se forte inserção política e burocrática dos agentes, apontando articulação com a alta esfera do governo e do poder de Estado, implicando passagem por diversas instâncias de cúpula como: Câmara dos Deputados, Senado, Conselho de Estado e Conselho de Ministros, além da presidência de províncias.

Essa descoberta permite inferir que o investimento em interpretação constitucional, naquele momento fundacional do constitucionalismo brasileiro, não partiu predominantemente da docência jurídica, não tendo por norte a ação de "homens exclusivamente da ciência", mas foi ferramenta mobilizada pela elite política composta por senadores, deputados, conselheiros de Estado e presidentes de província, por burocratas e magistrados, homens com experiência docente e/ou jornalística. Note-se que essa elite de Estado atuou no mesmo período em que se constituiu a tradição extra-acadêmica do "bacharelismo liberal" (Adorno, 1988).

No panteão dos constitucionalistas do Segundo Reinado esteve mobilizada uma verdadeira nobreza de Estado, no sentido empregado por Bourdieu (2013). Portanto, os manuais de direito público e constitucional repercutiram demandas do poder de Estado, formatadas no molde conservador pelo perfil generalista, neutralista e universalista do debate técnico-constitucional, contrastando na forma e no teor com a produção dos bacharéis liberais e, portanto, com sua expressão explicitamente militante, tendência originária, especialmente dos acadêmicos de direito da escola paulista.

\section{Conclusão}

Como prática das elites brasileiras, a formatação jurídica das batalhas políticas no Segundo Reinado foi sistemática. Por tal razão, é importante incluir o constitucionalismo no plano dos objetos de estudo da ciência política, com vistas a demonstrar, a partir de fundamentos empíricos, como se processa o investimento de frações da elite na legitimação de um regime político, através da mobilização do direito. Mais do que o nascimento da ciência constitucional no Brasil, tem-se aí um verdadeiro manejo político do direito, pois o caso estudado apontou uma forma de mobilização política através da doutrina, engendrada pela fração da elite que assumiu coletivamente a condição de constitucionalista.

A relação entre as trajetórias e as publicações indicou que, para conquistar uma posição como publicista naquele contexto, não bastava, e nem mesmo era condição, ser professor. Em vez disso, se tratava em muitos casos de políticos-bacharéis multiposicionados, com investidura em carreiras burocráticas e políticas, muitos deles já situados no topo do escalão estatal, em postos reservados às esferas mais restritas da elite. Logo, a inserção política funcionou como fator de legitimação para o posto de intérprete da Constituição, somada ao conhecimento do direito e à "experiência prática" como advogado e/ou magistrado. 
Embora parcela dos professores dos cursos jurídicos imperiais também integre a amostra da população de autores de manuais jurídicos, isso seria fator indicativo de uma tendência geral, ainda que frágil e incipiente, de modelagem do espaço da doutrina jurídica como um lugar afeito à identificação entre ensino e "competência teórica". Dentre os agentes da produção de manuais de doutrina constitucional com passagens nas escolas de São Paulo e Olinda/Recife como lentes, identificamos casos como os de Braz Florentino e Zacarias de Góis e Vasconcelos.

Dentre os achados da pesquisa, destaca-se que, apesar de a produção teórica não se constituir em exigência para o ingresso na carreira docente, administrativa ou política - e de a carreira docente jurídica não ser tão atrativa às elites quanto as funções políticas -, houve um volume significativo de investimento na produção de manuais de doutrina constitucional desde 1824 até 1885 , que se intensificou a partir de 1850 . Logo, torna-se relevante observar de modo mais aprofundado os trajetos dos agentes que, em cada contexto brasileiro, se projetaram como intérpretes da Constituição e que nem sempre foram, exclusivamente, docentes das escolas de direito.

No caso do Segundo Reinado, verificou-se a convergência de fatores aparentemente paradoxais, como a longevidade da influência luso-brasileira (que não valorizava a produção científica e a atividade docente) e a estratégia conservadora da promoção do publicismo, para a sustentação do regime monárquico, do Poder Moderador, do Conselho de Estado e da vitaliciedade do Senado. Somados, esses fatores contribuíram para solidificar uma posição jurídico-doutrinária dominante, repercutindo os interesses dos políticos do campo conservador e sua posição superior na hierarquia política do Império.

A interpretação constitucional mobilizada no Segundo Reinado através da doutrina não serviu apenas como suporte aos debates jurídicos entre especialistas, mas repercutiu posições políticas dos agentes, que foram simultaneamente juristas e homens da política. Os trajetos desse grupo demonstram que o publicismo jurídico integrou os esforços da elite política do Segundo Reinado para gerar a maior eficácia simbólica possível em favor da manutenção do regime monárquico, funcionando como elemento aglutinador em torno da causa centralista e da opção monárquica.

Se os políticos situados em posições centrais da esfera política e estatal difundiram suas teses jurídicas conformando um pensamento de Estado, e, portanto, um pensamento político, este não fora emanado tão somente da tribuna do Parlamento e dos atos do Executivo, mas também por meio das suas obras jurídicas. Com isso, fizeram política a partir do direito e contribuíram para moldar a vinculação entre a dimensão doutrinária e o ativismo político. Personagens identificados com o núcleo da política saquarema (como o Marquês de São Vicente e o Visconde do Uruguai) e luzia (como o Conselheiro Zacarias de Góis e Vasconcelos) estiveram no centro da mobilização do constitucionalismo, delineando a doutrina como lugar privilegiado da relação entre os campos jurídico e político, um espaço fluído e de fronteiras porosas, voltado, predominantemente, à tarefa de legitimação teórica do Estado. Assim, o publicismo integrou o processo de unificação da cultura política de 
feição conservadora durante o Segundo Reinado.

Portanto, é importante frisar que o discurso legitimador da ordem conservadora e sua contestação liberal, formatados em discussão constitucional, não representaram uma produção isolada de docentes, mas constituíram-se em investimento coletivo pelo qual frações hegemônicas da elite política do período atuaram, ao lado de professores, escritores e jornalistas, delimitando e contendo a discussão política nos limites do campo do poder estabelecido, ou seja, excluindo do debate jurídico aspirações de forte impacto político à época, como o abolicionismo e o republicanismo. Figuras relevantes do Partido Saquarema ou Conservador e do Partido Luzia ou Liberal, protagonistas da esfera política, também buscaram definir, durante o Segundo Reinado, o tom do debate constitucional. A pesquisa sócio-histórica sobre o caso exemplar da estratégia de construção do saber oficial sobre o Estado (e emanado do próprio Estado) no Segundo Reinado contribui para explicar as condições da exclusão de temas como abolicionismo, republicanismo e federalismo do âmbito da doutrina constitucional.

No entanto, a mobilização política da doutrina jurídica não é fenômeno circunscrito a um cenário específico, mas sim prática longeva na sociedade brasileira, tanto quanto é antigo no Brasil o apego das elites em edificar a "moldura constitucional" dos regimes. Haja vista a sucessiva entrada em cena de uma "nova Constituição" (o que ocorreu em 1891, 1934, 1937, 1946, 1967-1969 e 1988), deve-se investigar também em que condições e por quem foi "interpretada". Problematizar os usos do publicismo em cenários e momentos distintos é fundamental para obter um panorama das estratégias das elites para assegurar, já desde a fundação do Estado nacional, o seu domínio na legitimação da ordem política.

Dessa forma, sugere-se o aprofundamento dos estudos sobre as condições sociais da construção doutrinária das causas políticas, abarcando outros marcos temporais e espaços (como o partidário, o burocrático, o corporativo, o sindical, o religioso e o dos movimentos sociais). Se a adoção de instituições é um ato político, interpretá-las também o é. Assim, a abordagem sócio-histórica aplicada ao plano doutrinário pode nos revelar mais sobre os contornos estruturais da luta política que - para além da dimensão conjuntural - estão inscritos na força simbólica dos discursos.

\section{Referências bibliográficas}

Adorno, S. Os aprendizes do poder: o bacharelismo liberal na política brasileira. Rio de Janeiro: Paz e Terra, 1988.

Agrikoliansky, E. Les usages protestataires du droit. In: FillieUle, O.; AgrikolianSKY, E.; SOMmier, I. (dirs.). Penser les mouvements sociaux. Paris: La Découvert, p. 225-243, 2010.

AlECRIM, O. Ideias políticas no Império: influências francesas. Brasília: Senado Federal, Conselho Editorial, 2011. 
O PUBLICISMO E A POLÍTICA CONSERVADORA DO BRASIL NO SÉCULO XIX

ALMEIDA, C. B. "A prosopografia ou biografia coletiva: limites, desafios e possibilidades". In: Anais do XXVI Simpósio Nacional de História (ANPUH). São Paulo, p. 1-9, 2011.

AlmeidA, F. N. R. "A nobreza togada: as elites jurídicas e a política da justiça no Brasil". Tese de Doutorado em Ciência Política. São Paulo: Universidade de São Paulo, 2010.

Alonso, A. Ideias em movimento: a geração 1870 na crise do Brasil Império. São Paulo: Paz e Terra, 2002.

Ambrosini, D. R.; Ferreira, G. N. Primeira Seção Império: 1850-1889. In: MotA, C. G.; FerreirA, G. N. (coords.). Os juristas na formação do Estado-Nação brasileiro. São Paulo: Saraiva, 2010.

Arantes, R. Ministério Público e Política no Brasil. São Paulo: Educ, 2002.

BARMAN, R.; BARMAN, J. "The role of the law graduate in the political elite of the Imperial Brazil". Journal of Interamerican Studies and World Affairs, vol. 18, n० 4, 1976.

BARreto, V.; PAim, A. Evolução do pensamento político brasileiro. Belo Horizonte: Itatiaia; São Paulo: Edusp, 1989.

BlAKE, A. V. A. S. Diccionario bibliographico brazileiro. Rio de Janeiro: Imprensa Nacional, vol $n^{\circ} 5$, 1899.

Blanquer, M.; Millet, M. L'intervencion de l'État. Léon Duguit, Maurice Hariou et la naissance du droit public moderne. Paris: Odile Jacob, 2015.

Bonelli, M. G. Profissionalismo e política no mundo do direito. São Paulo: Edufscar, 2002.

Botelho, A.; Ferreira, G. N. (orgs.). Revisão do pensamento conservador: ideias e política no Brasil. São Paulo: Hucitec, 2010.

BOURDIEU, P. "Décrire et prescrise: note sur les conditions de possibilite et les limites de l'eficacité politique". Actes de la Recherche en Sciences Sociales, vol. 38, p. 69-73, maio 1981.

Bourdieu, P. La nobleza de Estado. Educación de elite y espíritu de cuerpo. Buenos Aires: Siglo Veintiuno Editores, 2013.

Letras, 2014.

. Sobre o Estado: cursos no Collège de France (1989-1992). São Paulo: Companhia das

"La force du droit. Eléments pour une sociologie du champ juridique". Actes de

la Recherche em Sciences Sociales, vol. 64, p. 3-19, 1986.

BrASILIENSE, A. Os programas dos partidos e o Segundo Império. Brasília: Senado Federal; Rio de Janeiro: Fundação Casa de Rui Barbosa, 1979.

Burgos, M. B.; ViAnNA, L. W. A judicialização da política e das relações sociais no Brasil. Rio de Janeiro: Revan, 1999.

Buton, F.; MARIOT, N. (orgs.). Pratiques et méthodes de la socio-histoire. Paris: Presses Universitaires de France, 2009.

Carvalho, J. M. A construção da ordem: a elite imperial. O teatro das sombras: a política imperial. Rio de Janeiro: Civilização Brasileira, 2006.

. (org.). Paulino José Soares de Sousa, Visconde do Uruguai. São Paulo: Editora 34, 2002. 
Carvalho, J. M.; NeVes, L. M. B. P. (orgs.). Repensando o Brasil do oitocentos: cidadania, política e liberdade. Rio de Janeiro: Civilização Brasileira, 2009.

Centro de documentação do Pensamento Brasileiro (CDPB). Sítio do Centro de Documentação do Pensamento Brasileiro <www.cdpb.org.br>. Salvador, 2008. Acesso em: 27 ago. 2013.

ChARLE, C. "La bourgeoisie de robe en France au XIX siècle". Le Mouvement Social, no 181, out.-dez., p. 55-72, 1997.

Chevallier, J. Les interprètes du droit. In: Poirmeur, Y.; Bernard, A. (orgs.). La doctrine juridique. Paris: Presses Universitaires de France, p. 259-280, 1993.

Chevallier, J.; Lochak, D. "Les juristes dans I'espace public". Droit et Société, vol. 93, no 2, p. 359374, 2016.

Commaille, J.; Dumoulin, L.; ROBert, C. (orgs.). La juridicisation du politique. Paris: LGDJ, 2010.

CoRAdini, O. L. (org.). Estudos de grupos dirigentes no Rio Grande do Sul. Algumas contribuições recentes. Porto Alegre: Editora da UFRGS, 2008.

CostA, E. V. Da monarquia à república: momentos decisivos. São Paulo: Unesp, 2007.

DÉLOYE, Y. Sociologie historique du politique. Paris: La Découvert, 2007.

DEZALAY, Y. La production doctrinale comme objet en terrain de lutes politiques et professionnelles. In: Bernard, A.; PoIrmeur, Y. (orgs.). La doctrine juridique. Paris: Presses Universitaires de France, p. $240-258,1993$.

DeZALAY, Y.; GARTH, B. "A construção jurídica de uma política de notáveis: o jogo duplo da elite do Judiciário indiano no mercado da virtude cívica". Revista Pós Ciências Sociais (Repocs). Dossiê Profissões e Espaços da Política, São Luís do Maranhão, vol. 12, no 23, p. 37-60, jan. jun. 2015.

DUTRA, P. Literatura jurídica no Império. Rio de Janeiro: Padma, 2004.

E-BiografiA. José de Alencar. [S.I.], 2014. Disponível em: <http://www.ebiografias.net/jose_alencar/>. Acesso em: 1 nov. 2016.

Engelmann, F. Sociologia do campo jurídico: juristas e usos do direito. Porto Alegre: Safe, 2006.

Engelmann, F.; PenNA, L. R. "Constitucionalismo e batalhas políticas na Argentina: elementos para uma história social". Revista Estudos Históricos. Rio de Janeiro, vol. 29, no 58, p. 505-524, 2016.

FAORO, R. Os donos do poder: formação do patronato político brasileiro. $15^{a}$ ed, vols. 1 e 2. São Paulo: Globo, 2000.

FAusto, B. História concisa do Brasil. São Paulo: Edusp, 2006.

Ferreira, G. N.; Botelho, A. (orgs.). Revisão do pensamento conservador. São Paulo: Hucitec; Fapesp, 2010.

FrançoIS, B. Naissance d'une Constitution: La Cinquieme République: 1958-1962. Paris: Presses de Sciences Po, 1996.

$385,2003$.

. Le droit saisi par la politique. In: LAGROYE, J. (org.). La politisation. Paris: Belin, p. 373- 
O PUBLICISMO E A POLÍTICA CONSERVADORA DO BRASIL NO SÉCULO XIX

GeneALogy Sérgio R Porto. [S.I.], 2013. Disponível em: <http://familytreemaker.genealogy.com/users/p/o/Sergio-R-Porto-Rio-deJaneiro/FILE/0004text.txt>. Acesso em: 29 out. 2013.

Grijó, L. A. "Ensino jurídico e política partidária no Brasil: a Faculdade de Direito de Porto Alegre (1900-1937)". Tese de Doutorado em História Social. Niterói: Universidade Federal Fluminense, 2005. . "A elite do Partido Republicano se apropria da 'Revolução'". Revista História Unisinos, vol. 14, no 1, p. 29-37, jan-abr. 2010.

Guedes, R. M. "Os meandros da tradução jurídica". Dissertação de Mestrado. Programa de PósGraduação em Letras Neolatinas. Rio de Janeiro: UFRJ-Faculdade de Letras, 2011.

HallewelL, L. O livro no Brasil. São Paulo: Edusp, 2012.

HolandA, S. B. (dir.). História geral da civilização brasileira. Tomo II - O Brasil monárquico. Vol. 5: Reações e transações. Rio de Janeiro: Bertrand Brasil, 2004.

JUNQUeIRA, J. R. "Permeando a curva da trajetória de José Carlos Rodrigues (1867-1923): breves apontamentos teórico-metodológicos". In: Anais do Simpósio Nacional De História, São Paulo, 2011.

Koenner, A. Judiciário e cidadania na Constituição da República brasileira (1841-1920). Curitiba: Juruá, 2010.

Kugelmas, E. (org.). José Antônio Pimenta Bueno, Marquês de São Vicente. São Paulo: Editora 34, 2002.

LACROIX, B.; LAGROYE, J. (orgs.). Le président de la République: usages et genèses d'une institution. Paris: Presses de la Fondation Nationale des Sciences Politiques, 1992.

LYNCH, C. E. C. Quando o regresso é progresso: a formação do pensamento conservador saquarema e de seu modelo político (1834-1851). In: BotelHo, A.; FERREIRA, G. N. (orgs.). Revisão do pensamento conservador: ideias e política no Brasil. São Paulo: Hucitec, 2010.

MatTos, I. R. O tempo saquarema. São Paulo: Hucitec; Brasília: INL, 1987.

Mercadante, P. A consciência conservadora no Brasil. Contribuição ao estudo da formação brasileira. Rio de Janeiro: Topbooks, 2003.

MotA, C. G. ; Ferreira, G. N. (coords.). Os juristas na formação do Estado-Nação brasileiro. São Paulo: Saraiva, 2010.

NeVES, L. M. B. P. Corcundas e constitucionais: a cultura política da Independência (1820-1822). Rio de Janeiro: Revan; Faperj, 2003.

Nogueira, O.; Firmo, J. S. Parlamentares do Império. Brasília: Centro Gráfico do Senado Federal, 1973.

Oliveira, C. H. S. (org.). Zacarias de Góis e Vasconcelos. São Paulo: Editora 34, 2002.

PARAnhos, A. R. "Ideias jurídico-políticas de José de Alencar: 1855-1877". Dissertação de Mestrado em História. Niterói: Universidade Federal Fluminense, 2013.

Poirmeur, Y. Thèmes et dèbats autour du constitutionnalisme. In: Chevallier, J. (org.). Droit et politique. Paris: Presses Universitaires de France Paris, p. 13-39, 1993.

Poirmeur, Y.; Bernard, A. La doctrine comme objet. In: Poirmeur, Y.; Bernard, A. (orgs.). La doctrine juridique. Paris: Presses Universitaires de France, p. 5-12, 1993. 
POIRMEUR, Y.; ROSENBERG, D. La doctrine constitutionnelle et le constitutionnalisme français. In: LOCHAK, D. (org.). Les usages sociaux du droit. Paris: Presses Universitaires de France, p. 230-251, 1989.

Prado, M. E. (org.). Dicionário do pensamento brasileiro: obras políticas do Brasil Imperial. Rio de Janeiro: Revan, 2012.

. (org.). O Estado como vocação: ideias e práticas políticas no Brasil Oitocentista. Rio de Janeiro: Access Editora, 1999.

Ribeiro, G. S.; FerreirA, T. M. T. B. C. (orgs.). Linguagens e práticas da cidadania no século XIX. São Paulo: Alameda, 2010.

Rodrigues, J. H. Teoria da história do Brasil: introdução metodológica. 4a ed. São Paulo: Editora Nacional; Brasília: INL, 1978.

Rodrigues, A. M. M. "Visconde do Uruguai e a ética do estadista". Revista Estudos Filosóficos, nº 7, p. 139-152, 2011.

Rodrigues, J. H. A Assembleia Constituinte de 1823. Petrópolis: Vozes, 1974. Editora, 1975.

Independência: revolução e contra-revolução. Rio de Janeiro: Livraria Francisco Alves

SACRISTE, G. La Republique des Constitutionnalistes: professeurs de droit et légitimation de I'État en France (1870-1914). Paris: Presses de Sciences Po, 2011.

Saldanha, N. N. História das ideias políticas no Brasil. Brasília: Senado Federal/Conselho Editorial, 2001.

Silva, F. T. "História e ciências sociais: zonas de fronteira". Revista História, São Paulo, vol. 24, no 1, p. $127-166,2005$.

SIMÕES, F. T. "Os bacharéis na política, a política dos bacharéis". Tese de doutorado em ciência política. São Paulo: Universidade de São Paulo, 1983.

SODRÉ, N. W. Panorama do Segundo Império. Rio de Janeiro: Graphia, 2004.

Stone, L. "Prosopografia". Revista de Sociologia e Política, Curitiba, vol. 19, nº 39, p. 115-137, 2011.

STF - Supremo Tribunal Federal. Sítio do Portal do Supremo Tribunal Federal <www.stfjus.br>. Brasília, 2013. Acesso em: 27 ago. 2013.

VECCHIOLI, V. "Uma história social da expertise em direitos humanos: trajetórias transnacionais dos profissionais do direito na Argentina". Estudos Ibero-Americanos, Porto Alegre, vol. 45, no 1, p. 1728, jan.-abr. 2019.

VenÂncio Filho, A. Das arcadas ao bacharelismo: 150 anos de ensino jurídico no Brasil. São Paulo: Perspectiva, 2005.

VIANNA, L. W. Os intelectuais da tradição e a modernidade: o caso dos juristas-políticos da OAB. In: SOARES, M. S. (org.). Os intelectuais nos processos políticos da América Latina. Porto Alegre: Editora da UFRGS, p. 191-224, 1985. 


\begin{abstract}
Publicism and conservative politics of Brazil in the XIX century

This article focuses on the political uses of the Law, more specifically on the way that fractions of the Brazilian imperial elite mobilized discourses. The main goal of this approach is to discuss the mobilization of legal knowledge in the context of the conflicts engendered in the 19th century about the definition of a model of State in Brazil, through socio-historical methodology. This research shows the uses of publicism, as well as the invention of constitutionalism, as strategies in the political game, which correspond to the rivalry between elites in the process of construction and legitimation of a regime with monarchical features and centralized.
\end{abstract}

Keywords: politics; lawyers; publicism; Brazil

\title{
Resumen
}

El publicismo y la política conservadora de Brasil en el siglo xix

Este artículo enfoca los usos políticos del Derecho, más específicamente los discursos movilizados por fracciones de la elite política imperial brasileña en formato de publicismo. El objetivo de este enfoque es el de discutir la movilización del conocimiento jurídico en el ámbito de las luchas desencadenadas en el siglo XIX sobre la definición del modelo de Estado en Brasil a través de la metodología sociohistórica. La investigación muestra los usos del publicismo y la invención del constitucionalismo como armas del juego político, que corresponden a la competencia intra-elites en el proceso de construcción y legitimación de un régimen político de aspecto monárquico y centralizado.

Palabras clave: política; juristas; publicismo; Brasil

\section{Résumé}

Le publicisme et la politique conservatrice du Bresil au xixe siecle

Cette article ciblant sur le thème des usages politiques du Droit et plus particulièrement sur la mobilisation du discours des fractions de l'élite impériale brésilienne au format de publicisme. L'objectif de cette approche est de discuter de la mobilisation des connaissances juridiques au sein des luttes déclenchées au XIX ${ }^{\mathrm{e}}$ siècle sur la définition du modèle d'État au Brésil, à travers la méthodologie sociohistorique. La recherche montre les usages du publicisme et l'invention du constitutionnalisme comme des armes du jeu politique, qui correspondent à la concurrence intra-élites dans le processus de construction et légitimation d'un régime politique de moulage monarchique et centralisée.

Mots clés: politique; les juristes; le publicisme; Brésil

Artigo submetido à publicação em 22 de julho de 2018. Versão final aprovada em 2 de agosto de 2019.

Opinião Pública adota a licença Creative Commons CC-BY.

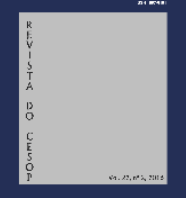

